\title{
Dediščina soške fronte v luči heterotopij, utopij in drugih »drugih prostorov $\ll$
}

BoštJan KRAVANJa

Heterotopije so posebne vrste prostori, ki s tem da v širši prostor vnašajo določeno iluzijo, sprevračajo in spreminjajo obstoječi red stvari. Ker različne prostore (in njihove kraje) postavljajo v nova medsebojna razmerja, so primeren koncept za obravnavo sodobnih dediščin, še posebno tistih, ki naslavljajo neskladne oziroma težavne epizode človeške zgodovine, med katere sodi tudi dediščina soške fronte. Prvi je pojem heterotopij predstavil Michel Foucault (1984) leta 1967. Zanj so heterotopije »drugi prostori«, ki se udejanjajo v različnih tipičnih oblikah, kot so na primer zapori, psihiatrične bolnišnice, bordeli, domovi za starostnike in podobne institucije, ki »urejajo « različne krize ali deviacije. Lahko pa so to tudi kraji utopičnih zrcal, ki se nanašajo na druge prostore in čase (festivali, pokopališča, muzeji, knjižnice, parki, ladje in podobno). 
$S$ konceptom heterotopij so kasneje različni avtorji obravnavali medsebojno zelo različne tipe prostorov: od arhitekturnih ureditev, umetniških instalacij, knjižnic, muzejev, trgovskih omrežij, vrtov, svetih krajev, pokopališč in plaž do kibernetskih prostorov, spletnih strani, socialnih omrežij in podobnega (glej Johnson 2016b: 6). V vseh teh obravnavah so avtorji koncept različno razumeli in ga včasih uporabljali celo diametralno nasprotno. ${ }^{\mathbf{1}}$ Heterotopologija tako ni koherentna teorija, ampak bolj metoda za analizo večpomenskih in večfunkcionalnih prostorov (Johnson 2016b:3-4), v katerih se različne utopije, iluzije in fantazije na poseben način prostorsko udejanjajo oziroma lokalizirajo. Heterotopije so torej »realizirane utopije, v katerih so realni položaji, vsi drugi realni položaji, ki jih je mogoče najti znotraj kulture, hkrati reprezentirani, spodbijani in prevrnjeni« (Babič 2009: 123; Johnson 2016b: 9).

Dediščina soške fronte se je začela vzpostavljati z ustanovitvijo Kobariškega muzeja prve svetovne vojne leta 1990 in v slabih tridesetih letih postala kompleksen prostor, ki ga sestavljajo različne, tudi medsebojno nasprotujoče si naracije. Tako je izpostavljanje ključnih vojaških operacij in tehnoloških specifik soške fronte v nasprotju z obeleževanjem spomina na njene žrtve. Tudi poudarjanje trpljenja vojakov in prebivalstva, ena od rdečih niti Kobariškega muzeja in drugih krovnih institucij dediščine soške fronte, vsebinsko ni povsem kompatibilno s spominom na žrtve, ki je prežemal promocijo skupne nadnacionalne identitete Evropske unije v času obeleževanja stoletnic prve svetovne vojne (2014-2018). Spomin na samo vojno in življenje v njej je namreč drugačna naracija od smrti in žrtev za domovino ali imperij, pri različnih občinstvih pa tudi zbuja drugačna občutja.

Tudi prevpraševanje prihodnosti te dediščine je prepredeno z različnimi medsebojno izključujočimi se vsebinami in naracijami. Tako je treba kontemplativni spomin na žrtve vojne strateško vključiti $\mathrm{v}$ prostor, in to kljub njegovi nekompatibilnosti s praksami prostočasnega turizma, pohodništva in kolesarstva v naravi; iz dosjeja za Unescov stalni seznam svetovne kulturne dediščine je treba strateško izključiti vojaškooperativne ostaline, ker so nekompatibilne s trenutno Unescovo politiko dediščin modernih vojn (Kravanja 2018b: 117-18); novih vojaških bunkerjev, jarkov in drugih znamenitosti soške fronte heterotopijo, liminalni, protipolitični in protiekonomski prostor igre in prostega časa, drugim pa osrednjo ikono ameriških potrošniških vrednot in s tem prostor temeljne ekonomske, družbenokulturne in politične aktivnosti (po Johnson 2016b: 3). 
na eni strani nima več smisla dodajati k obstoječi Poti miru in situ, ${ }^{2}$ ker je tovrstnih ostalin na Poti že dovolj, jih je pa na drugi strani smiselno - podobno kot amaterske zbirke vojaške opreme in drugih materialnih ostalin soške fronte (glej Kravanja 2018a) - strateško umestiti pod njeno institucional(izira)no okrilje.

Vse te in številne druge kontradiktorne vsebine so se skozi čas nalagale v krajino soške fronte (primerjaj Saunders idr. 2013), in sicer ne tako, da bi druga drugo izpodrivale, ampak tako, da sobivajo v vedno bolj nagnetenem dediščinskem prostoru. $V$ tem smislu različne vsebine dediščine soške fronte zavzemajo različne položaje in se prilagajajo različnim spreminjajočim se redovom, hkrati pa nekatere od njih ustvarijo svoj specifičen red. Predvsem slednje so predmet pričujočega poglavja, saj pri njih ne gre le za prezenco v obliki avtentičnega kraja, ampak tudi za latenco, ki se venomer vrača in udejanja v ugodnih trenutkih kot neodvisna umestitev ali zavzetje določenega položaja, ki spremeni vse druge položaje v dediščini (Babič 2009: 122-23; Johnson 2016b: 9).

V tem poglavju torej dediščinski prostor soške fronte obravnavam kot niz ali omrežje »drugih prostorov« (Foucault 1984), heterotopij, ki jih povezuje ideja dobre (to je eutopične) krajine, pri čemer se pojem eutopije $\mathrm{j}^{\mathbf{3}}$ nanaša na tri stvari: v prvem času je to iskanje idealnega prikaza osrednje bitke soške fronte, v drugem je v ospredju ideja miru, ki jo popularizirajo številni sodobni dediščinsko preoblikovani kraji vojnih spopadov, pokolov in podobnega (glej na primer Ziino 2012: 151), v tretjem pa se odraža v predstavah o kulturnem turizmu kot odrešilni dejavnosti, ki bo v dolino Soče privabila obiskovalce, željne zgodovinskih naukov in kontemplacije ob žrtvah vojne vihre.

Te tri različne (e)utopije, osrednja bitka, ideja miru s skupno evropsko identiteto in prepričljivost turističnih produktov na temo soške fronte, so se zadnja tri desetletja v prostoru dediščine soške fronte udejanjile v obliki različnih heterotopij. Njihovo idejno ozadje je mogoče primerjati s triado antagonističnega, agonističnega in kozmopolitskega načina spominjanja na pretekle konflikte (glej Cento Bull je ta tematska pot vzdolž frontnih linij pod imenom Poti miru v Zgornjem Posočju obsegala 100 km, med letoma 2012 in 2015 pa je bila razširjena na 300 km dolgo Pot miru od Alp do Jadrana.

3 Ideja miru naslavlja tudi skupno zgodovinsko usodo ter tako z besedno igro (»EUtopija «) aludira na Evropsko unijo kot enega temeljnih mirovnih projektov in snovalk nadnacionalne identitetne politike $\mathrm{v}$ današnjem času. 
in Hansen 2016). ${ }^{4}$ Toda v tem poglavju me zanima korak pred tem, in sicer, kako se različne dediščinske usmeritve in poudarki lokalno odražajo v prostoru ne glede na uveljavljene načine spominjanja. Ti v igro eventualno vstopijo šele post festum, ko prek interakcij z različnimi drugimi akterji, institucijami in ne nazadnje občinstvi sproti prilagajajo panoramski pogled na dediščino in enkrat poudarijo ta, drugič oni vidik, same dediščine pa ne morejo preurediti v temeljih in v celoti, ker je to stvar zadevne prakse vsakega segmenta posebej in ne kontekstualizacije, reprezentacije, strukturnih sprememb in podobnega.

Odkar namreč ta dediščina obstaja v moderni obliki, torej od ustanovitve Kobariškega muzeja prve svetovne vojne leta 1990 in ustanove Fundacija Poti miru v Posočju leta 2000 (v nadaljevanju Fundacija), je trud za njeno enotno podobo prepreden z improvizacijo, ki se na eni strani ukvarja z zadovoljevanjem, usklajevanjem, sprejemanjem in izključevanjem notranjih krajevnih pobud, na drugi pa venomer išče potencialne druge redove, ki se porajajo iz živahne dediščinske industrije, znanosti, turističnorazvojnih diskurzov ter identitetne politike na nacionalnih, čezmejnih in mednarodnih ravneh (glej npr. Kravanja 2018b). Sprememb te dediščine tako tudi ne moremo razumeti samo v smislu nalaganja zgodovinskih »plasti« (layer), ki se druga čez drugo celotno dvajseto stoletje v dolino Soče vpisujejo kot »konfliktne krajine soške fronte « (glej Saunders idr. 2013). Tu pokažem na praktične vidike tega procesa in podrobneje ugotavljam načine, na katere se tovrstne »plasti« uprostorjajo kot heterotopije, torej ne da bi se umestile na določen »avtentičen « fizični kraj, saj je prav irelevantnost kraja tisto, kar heterotopiji zagotavlja položaj $\mathrm{v}$ krajini in s tem spremembo vseh drugih tamkajšnjih položajev.

\section{HETEROTOPIJE KOT »DRUGI PROSTORI«}

Michel Foucault je v svojem razmišljanju o prostorskih metaforah dvajsetega stoletja $\mathrm{v}$ filozofijo in humanistiko prvi vpeljal pojem 
heterotopije (glej Foucault 1984). Pojma sicer kasneje ni izostril do take mere, da bi ga bilo mogoče razumeti brez preostankov, je pa bil nenavadno dobro sprejet pri številnih drugih avtorjih, ki so ga, kot sem že navedel v uvodu, uporabljali in razvijali za naslavljanje različnih prostorskih hibridov z vidika različnih moči, ki so udeležene pri (pre) urejanju prostora (glej Johnson 2012b).

Foucault (1984) je svoje inicialno predavanje $O$ drugih prostorih (Des espace autres) iz leta 1967, kjer je prvič govoril o heterotopijah, uvedel $\mathrm{z}$ dihotomijo med srednjeveško hierarhično ureditvijo prostora na eni strani in Galileievo metaforo odprtega prostora iz sedemnajstega stoletja na drugi. Prva je temeljila na opozicijah med svetim in profanim, zavarovanim in izpostavljenim, urbanim in ruralnim, nebeškim in zemeljskim, druga pa na koncepciji odprtega prostora v gibanju in njegovem neskončnem širjenju. $Z$ uveljavljanjem slednjega so se nato razvile nove tehnike za prilastitev, zamejevanje in formaliziranje prostora; začele so nastajati nove klasifikacije, $\mathrm{v}$ okviru katerih so bili kraji medsebojno povezani v nov red (1984: 2).

Toda Galileieva sekularizacija prostora se v praksi ni povsem udejanjila. Prostor, v katerem živimo, pravi Foucault (1984: 2), ni niti homogen niti prazen, ampak prepojen $s$ kvalitetami, ki jih posredno še vedno razumemo kot svete (na primer očitne opozicije med zasebnim in javnim, družinskim in družbenim, kulturnim in uporabnim, prostočasnim in delovnim prostorom). Toliko bolj pa je ta »skrita prisotnost svetega « transparentna v današnji pluralistični, kaotični in skozi detajle (po)ustvarjeni geografiji, ki ji manjka univerzalnih temeljev in načel, označena pa je z globokimi družbenimi neenakostmi. Konkretni kraji v taki geografiji postanejo fantazme (svetega), vanje penetrirajo oddaljeni vplivi, njihova izkušnja pa je s pomočjo sofisticiranih tehnologij, zaslonov, prikazov, razstav, tematskih parkov in podobnega polisemična oziroma $\gg$ multilokalna « (glej Rodman 2003; primerjaj Babič 2009: 128-29). ${ }^{\mathbf{5}}$

Ta geografija se nenehno spreminja, poganjajo pa jo vrzeli, ki vznikajo iz medsebojno tekmujočih in prekrivajočih se konceptualnih in kulturnih redov, ki si vsak zase prizadevajo ustvariti čim bolj 
poenoten in regulativni prostor (Meijer-van Mensch 2017: 25). V praksi to pomeni, da različne subjektivne, kreativne in amaterske pobude pri soustvarjanju pomembnih fizičnih krajev trčijo ob njihovo družbeno konstrukcijo, trdno vzpostavljen ideološki okvir, ki je sam po sebi sicer kompleksen, v okvirih turističnorazvojnih diskurzov tudi prepusten (Kravanja 2018a: 101), pa vendarle potencialno dovolj regulativen, da ga je mogoče označiti kot »homogeno pošast « (Meijer-van Mensch 2017: 25).

Iz te dvojnosti med empiričnim redom stvari in njegovo interpretacijo v okvirih načel in zakonov, ki so postavljeni kot univerzalni, torej vznika vmesni, posredniški prostor, v katerem se stvari ločijo od tega primarnega empiričnega, $s$ kulturo usklajenega spontanega reda in se s tem same po sebi odprejo možnim reorganizacijam. Manifesten postane sam red, medtem ko se »zdravorazumska « percepcija stvari in njihovo empirično urejanje pomakneta $\mathrm{v}$ sfero razmišljanja o drugih možnih redovih. $V$ tem smislu postane urejanje stvari spremenljivo, nestalno in pogosto definirano z oddaljenimi sistemi koherence (Foucault 2002: xxii-xxiii). V tej vmesni, posredniški sferi prostora se torej vsakokratni red uveljavlja kot samoumeven, čeprav je hkrati tudi nepopoln. Foucault pravi:

$\mathrm{V}$ vsaki kulturi je torej med uporabo tega, čemur lahko rečemo urejevalne kode, in refleksijo samega reda čista izkušnja reda in njegovih načinov obstajanja. (Foucault 2002: 2002: xxiii)

Te čiste izkušnje reda pa ne kaže razumeti izven polisemij njegovega ustvarjanja, kar pomeni, da je ključni korak k njej prav zavest, da določen red pri stvareh sploh obstaja in da lahko ostane pri njem, lahko pa tudi ne. Foucault je to vprašanje razvoja epistemologije zahodne kulture od šestnajstega stoletja dalje poglobljeno raziskoval na širših področjih jezika, biologije in politične ekonomije (2002). Predhodno je s pomočjo koncepcij norosti pokazal, kako je (zahodna) kultura zamejila razlike in s tem svoje meje (glej Foucault 1998), v delu Besede in reči (Foucault 2002) pa je raziskal izkušnjo bližine med stvarmi in urejanja podobnosti med njimi (2002: xxvi). Njegova Zgodovina norosti je torej zgodovina (notranjega in zunanjega) Drugega (1998), Besede in reči pa naslavljajo zgodovino Istega, ki je hkrati razpršeno in medsebojno povezano $\mathrm{z}$ različnimi zvrstmi ali razredi, ki iz teh zbirk vedno znova (pre)urejenih stvari ustvarjajo identitete (Foucault 2002: xxvi).

Ko pa v okviru tega razmišljanja o zgodovini Istega in (ne) urejeni gneči stvari govorimo o krajih, se v tem procesu ustvarjajo heterotopije, specifični kraji, katerih značilnost je, da kot načeloma izključeni prostori reflektirajo nepopolnosti reda, v katerega se po sili 
vključujejo, s tem pa odpirajo možnosti za drugačen red (Babič 2009: 130). Teh novih možnosti hetorotopije ne črpajo iz antagonizma proti redu, ki izključuje, ampak iz samorefleksije in preurejanja lastnega reda, ko se pač stalno poskušajo usklajevati z različnimi drugimi redovi (glej Foucault 2002: xvi-xxvi). Heterotopije so »neke vrste kraji, ki so zunaj vseh krajev, čeprav so kljub temu dejansko lokalizabilni« (Babič 2009: 123). Predstavljajo tekstualni prostor utopij, »krajev (toposov), ki ne obstajajo (outopie) in so hkrati idealni kraji (eutopia) «(Johnson 2016a: 3). Toda za razliko od utopije, ki predstavlja red in koherentno celoto, je heterotopija kraj, kjer se ta red, ta odnos med besedami in rečmi, rahlja (Johnson 2016a: 3; Foucault 2002: xix).

Kot kraji kontradikcij, paradoksa, prostorsko-časovnih ambivalenc in fantazije se heterotopije umeščajo $\mathrm{v}$ homogeni prostor, kjer ni več prostora za karkoli »drugega «. Položaj si v tem prostoru utrejo bodisi kot $\gg$ drugi prostori «, ki pogosto implicirajo tudi druge čase (in so torej hkrati heterokronije) (Foucault 1984: 6-7), ali kot »drugo prostora « brez lokalizacije v obliki vsakdanjih praks in taktik alternativne rabe prostora (Babič 2009: 129-36). Heterotopologija je tako metoda semantičnega branja drugih, $\mathrm{v}$ konkretni krajini stalno spodbijanih prostorov in njihovih prostorskih posledic, katerih temeljna značilnost je relacijska kvaliteta; zmožnost kombiniranja neskladnih elementov, ustvarjanja mikrokozmičnih krajev, konkretizacije abstraktnih utopij in zavzemanja položaja ne glede na njihovo načelno izrinjenost (Johnson 2016b: 15-7; Foucault 1984: 4; Babič 2009: 131).

\section{METODOLOGIJA IN IZHODIŠČA}

Poglavje temelji na terenskem delu med različnimi upravljavci dediščine soške fronte $\mathrm{v}$ zadnjih nekaj letih, ko smo tej temi posvetili študijske terenske vaje pri predmetu Antropologija prostora na Oddelku za etnologijo in kulturno antropologijo Filozofske fakultete v Ljubljani. Vaje sva med letoma 2016 in 2018 pripravljala skupaj s kolegom Mihom Kozorogom (podrobneje o tem glej Kravanja 2018a: 102-4; Kravanja 2018b: 108). Predhodno (2011-2015) sem se na ta način z razvojem Zgornjega Posočja ukvarjal v okviru predmeta Antropologija turizma (glej Kravanja 2014: 94-7), vse te dragocene izkušnje pa sem nadgrajeval tudi z individualnimi terenskimi obiski. Večletno spremljanje dediščinskega in turističnorazvojnega prostora Zgornjega Posočja mi je ne nazadnje dalo možnost konceptualnih odmikov od 
zgolj opisne obravnave tamkajšnje dediščine in vpogled v njeno spreminjanje v daljšem obdobju.

Razmišljanje različnih akterjev, ki so (bili) na različne načine udeleženi pri upravljanju s to dediščino, me je utrdilo v prepričanju, da Poti miru od Alp do Jadrana, krovnega projekta Fundacije in posredno države Slovenije ter številnih drugih udeleženih dediščinskih institucij, ${ }^{6}$ ne kaže obravnavati kot enoznačnega sidrišča regulativnega ideološkega okvira, v katerem se vzpostavljajo temeljne usmeritve njene interpretacije (Kravanja 2018b; prim. 2018a). Ravno nasprotno: Pot miru je zgolj ena od trenutnih heterotopij, posredniški drugi prostor, v katerem se empirični red ostalin soške fronte preoblikuje tako, da s samorefleksijo v luči zunanjih in notranjih idejnih okvirov ter pobud vedno znova poustvarja, redefinira, spodbija in nevtralizira odnose med konkretnimi kraji dediščine soške fronte in nasploh Zgornjega Posočja.

Ker je dediščina soške fronte sama po sebi heterogena, ustvarjena iz raznolikih materialov, obravnavana $\mathrm{z}$ različnih vidikov in koncipirana z različnih izhodišč, lahko torej ob bližnjem etnografskem pogledu že govorimo o dediščinah soške fronte $\mathrm{v}$ množini. $\mathrm{V}$ tem le navidezno povezanem prostoru in $\mathrm{v}$ spreminjanju njegovih parcialnih pomenov vidim vrsto drugih prostorov, katerih » položaji [se] vzajemno implicirajo in zvajajo drug na drugega « (Babič 2009: 123). Stihijsko in improvizatorično ustvarjanje dediščinskega reda in situ je namreč natančno to, s čimer se danes primarno ukvarjajo tako krovni kot amaterski upravljavci dediščine soške fronte; to ni več ustvarjanje in širjenje zloščene zbirke ostalin soške fronte, temveč njihova interpretacija v vseh možnih okvirih, potencialno tudi tistih, ki s samo dediščino prve svetovne vojne in njeno konceptualizacijo nimajo prav veliko skupnega.

Heterogenost te dediščine je tako mogoče videti predvsem $\mathrm{v}$ veliki raznolikosti pristopov $k$ ohranjanju, restavriranju in (re)prezentiranju njenih materialnih ostalin. Njene vsebine se na eni strani umeščajo v okvir krovne dediščinske znamke Poti miru od Alp do Jadrana, na drugi pa ustvarjajo svoje druge prostore, ki naslavljajo lokalno zgodovino in vsaj nekateri ostajajo zunaj vpliva krovnih upravljavcev, čeprav so še vedno neločljiv del te dediščine kot celote (glej Kravanja

6

Poleg Kobariškega muzeja in Fundacije so pri snovanju zgodbe soške fronte in nasploh prve svetovne vojne pri nas udeležene številne muzejske, kulturne, izobraževalne in znanstvene institucije. Njihovo delovanje je $\mathrm{v}$ času obeleževanja stoletnic vojne usklajeval leta 2012 ustanovljeni Nacionalni odbor za obeležitev 100-letnic 1. svetovne vojne (Nacionalni odbor 2012; Klavora 2016: 134). 
2018a). V tem smislu so krovne institucije dediščine soške fronte s svojo dokumentacijo ter informacijsko in znanstveno podprto bazo podatkov predvsem posredniški, vmesni prostor, ki te zunanje in notranje vplive premešča in pogosto tudi nevtralizira, da podobo dediščine ohranja homogeno.

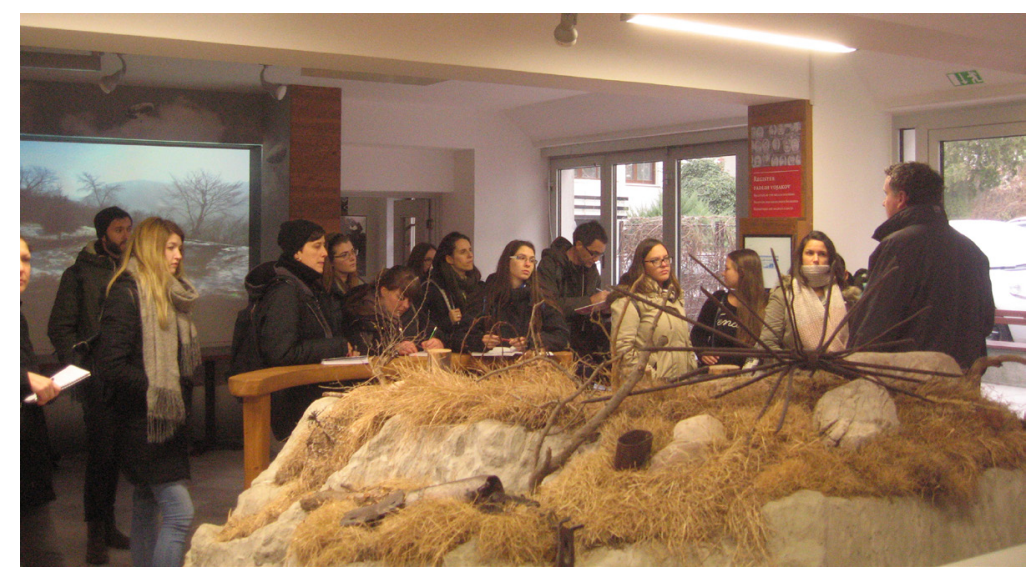

Slika 1: V prostorih Fundacije: uvod v terenske vaje iz Antropologije prostora 2017/2018 (foto: Boštjan Kravanja).

\section{VLOGA UPRAVLJAVCEV DEDIŠČINE SOŠKE FRONTE IN POMEN NJENIH MATERIALNIH OSTALIN}

Neposredni upravljavci dediščine, torej tisti, ki so pogosto $\gg$ zadnji v dolgi verigi kontingentnosti in delovanja, ki kraj vključuje v strukture dediščinske interpretacije in upravljanja « (Gegner in Ziino 2012: 4), so razpeti med dvema vrstama naracij. Prva je lokalno specifična, druga pa kontekstualna. Na prvi pogled je ugotavljanje zgodovinskih dejstev in predstavljanje krajevno specifične, faktualne zgodovine dogodkov, o katerih dediščina pripoveduje, veliko lažje kot ukvarjanje z njeno uravnoteženo reprezentacijo in s silnicami, ki to uravnoteženost venomer majejo. Ustvarjalci Poti miru so to drugo raven »razrešili« z evropskostjo svojega temeljnega mirovnega sporočila, a problem je $\mathrm{v}$ udejanjanju tega okvira v odnosu do različnih drugih podobnih dediščinskih prostorov (tako tistih $\mathrm{v}$ soseščini kot tistih zelo oddaljenih), različnih javnosti in lokalnih razvojnih pobud.

Lokalne pobude in razni amaterski navdušenci nad prvo svetovno vojno se niti ne morejo niti nočejo ukvarjati s pomenom in političnimi konteksti dediščinskih krajev, država pa ima s svojimi interesi 
$\mathrm{v}$ mednarodni in evropski politiki jasno agendo, pri kateri je faktualna zgodovina vojaških operacij, premikov frontnih črt in načinov bojevanja ter življenja vojakov na fronti potisnjena v ozadje in takorekoč rezervirana za » specialiste «. Teh ne manjka tudi v vrstah upravljavcev te dediščine, toda zaposleni na Fundaciji morajo predvsem krmariti med različnimi interesi različnih javnosti, financerjev, lokalnih, nacionalnih in mednarodnih političnih predstavnikov ter ne nazadnje lokalnih društev, zbiralcev, muzejskih delavcev, konservatorjev, turističnih menedžerjev, gostincev in drugih deležnikov.

Ohranjati morajo ravnotežje $\mathrm{v}$ ožjem okviru mirovnega sporočila Poti miru, hkrati pa tudi v odnosu do sosednjih Italijanov ter drugih bolj ali manj zainteresiranih in dejavnih predstavnikov narodov, ki so bili udeleženi na soški fronti. Upravljavci so hkrati sidrišče družbenih odnosov in identitet ter mediatorji drugih interesov, ker so $\gg$ procesi, ki so osrednji pri rekonstrukciji [ostalin], tudi tisti, ki so osrednji pri dediščini « (Gegner in Ziino 2012: 12). Z dediščino se tako morajo ukvarjati predvsem na simbolni ravni, saj se prek nje vzpostavljajo odnosi med ljudmi in skupnostmi. $\mathrm{V}$ tem smislu je dediščina vedno $\gg$ sporen proces, ki vključuje številne perspektive in zgodbe [...] številne interpretacije preteklosti, [ki] medsebojno tekmujejo za prevlado $\mathrm{v}$ regionalnih, nacionalnih in globalnih diskurzih « (Gegner in Ziino 2012: 14). Tako tudi restavriranje, konservacija in rekonstruiranje ostalin in situ ter razvoj materialnih ostalin $\mathrm{v}$ amaterskih zbirkah že v osnovi vključujejo tudi rekonstrukcijo dediščinske naracije, ki pa zaradi številnih kompromisov, ki jih zahteva teren, pogosto odstopa od izvorno zamišljenega simboličnega sporočila.

Napredek v urejenosti ostalin namreč poveča predvsem avtentičnost dediščine, kar je $\mathrm{v}$ osnovi pomembno tako za turistično politiko tukaj in zdaj kot tudi za mednarodno in nacionalno politiko, pri kateri objekti in zgodbe $\mathrm{v}$ krajini predstavljajo $\gg$ mnemonične naprave za kontekstualizacijo preteklosti in prihodnosti « (Gegner in Ziino 2012: 12). K povečanju avtentičnosti prispevajo predvsem znanstveno utemeljena faktualnost dediščine, kredibilnost njene dokumentacijske podlage, njena enotna podoba, dostopnost njenih ostalin, vzdržnost, ustrezen servis, izobraževalne vsebine in podobno. Toda sama realizacija in situ poteka tudi po drugih, »zdravorazumskih « in praktičnih tirnicah ter z drugimi deležniki, kar danes ni tuje niti znanstveni obravnavi te dediščine (glej Testen in Koren 2015) niti njeni amaterski različici zbiranja materialnih ostalin (Kofol 2015; Kravanja 2018a).

Idejna zasnova Poti miru se je kljub temu najprej oblikovala na simbolni, reprezentacijski in promocijski ravni, njena fizična raven pa je postala pomembna šele $\mathrm{v}$ zadnji fazi, ko je $\mathrm{v}$ ospredje prišlo urejanje 
turistične, pohodniške in kolesarske infrastrukture ter njena enotna podoba. S to zadnjo fazo so dediščinske prakse postale tudi življenjski pogoj vse več domačih prebivalcev, saj so se vse politične, družbene in kulturne implikacije začele na različne načine odražati tudi na konkretnih lokalnih ravneh (glej Gegner in Ziino 2012: 13).

Učinke promocije, koordinacije in pregleda nad dediščinskim prostorom navadni prebivalci pogosto razumejo zelo selektivno. Dediščina jim na primer prej kot orodje za promoviranje medsebojne tolerance, miru, znanja, solidarnosti in podobnega pomeni vse, kar je staro in »zgodovinsko «. Taka »čista « pričevalka preteklosti, ki je sama na sebi svéta, pa se lahko udejanja le v parcialnih projektih, ki se $\mathrm{v}$ našem primeru osredotočajo predvsem na značilnosti vojskovanja in tehnologije vojne, saj se to praktično znanje zdi ob goli pričevalnosti materialnih ostalin edino možno. Družbena realnost prebivalcev je namreč na eni strani daleč od svetih krajev dediščinsko preoblikovanih pokopališč in spominskih centrov, na drugi pa ji bojišča ponujajo več možnosti za produkcijo faktualnih naracij. Tako je bilo zbiranje materialnih ostalin, njihov študij, urejanje, izmenjevanje in podobno vedno pomembna stalnica teh krajev. V dolini Soče so bili ti materiali že takoj po vojni za mnoge vir preživetja, potem pa je to za nekatere postal zbirateljski konjiček, iz česar so se ne nazadnje razvili prvi nastavki za

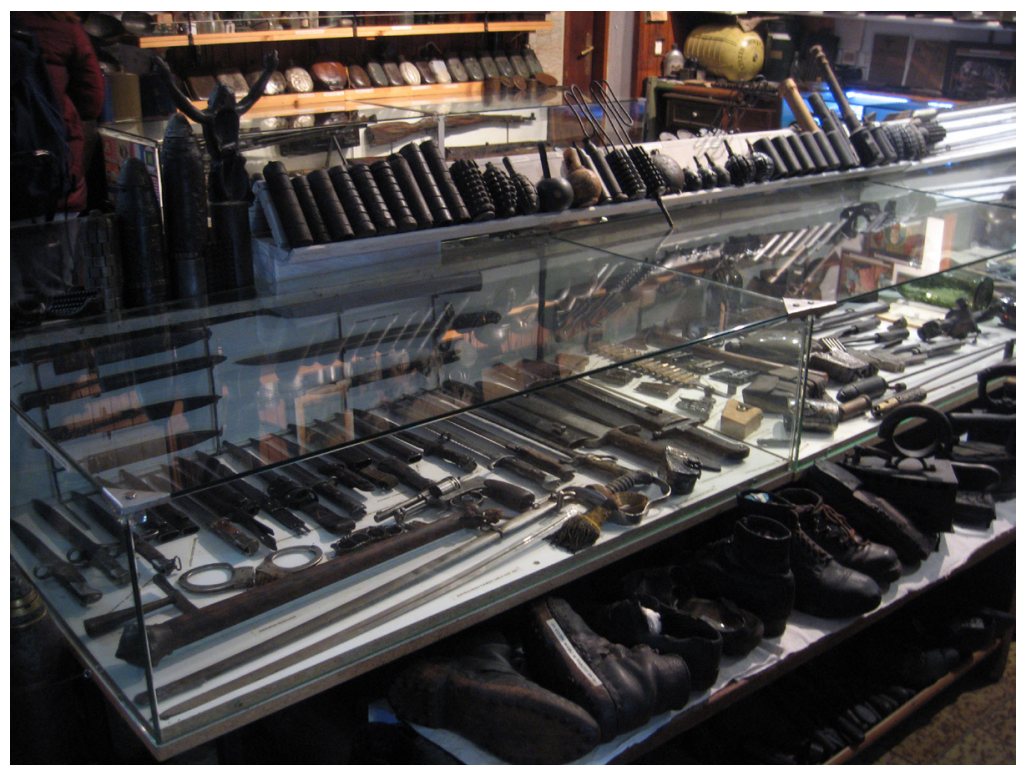

Slika 2: Segment vojaške opreme in orožja iz Etno-vojne zbirke družine Mazora v Breginju (foto: Boštjan Kravanja). 
ustanovitev Kobariškega muzeja, do danes pa se je ta dejavnost še bolj razmahnila med ljudmi (Kravanja 2018b: 107-10; 2018a).

Osredotočanje na bojišča, bitke in vojaške tehnologije pa ustvarja zgodovino » topovske krogle « (Sutton 2012: 113), pri čemer postanejo poleg premičnih artefaktov zanimive tudi fiksne ostaline $\mathrm{v}$ krajini, kot so različni bunkerji, kaverne, rovi, strateške vojaške točke in podobno. Tu se ne nazadnje odprejo možnosti za monopolizacijo posameznih mikrolokacij, za pravico do njihovega upravljanja, za specializacijo na določen ozek segment vojne, za njene lokalne zgodbe in tako naprej. Upravljavci morajo $\mathrm{v}$ teh primerih skrbeti za integracijo tega vrvenja posameznih prebivalcev in dediščinskih navdušencev ter odpreti narativni prostor, pri čemer brez dinamike vključevanja in izključevanja glede na številne zunanje dejavnike, ki zadevajo bolj promocijsko stran te dediščine, ne gre.

\section{KRAJ PRELOMNEGA DOGODKA IN VPRAŠANJE NJEGOVE AVTENTIČNOSTI}

Temeljno vprašanje vsake heterotopološke analize neke dediščine je, kako se kraji, kjer se je zgodil prelomni dogodek in zaradi katerih se je dediščina locirala tja in ne kam drugam, umeščajo v njen celoten niz ali omrežje. Kako torej prelomni, izredni, nenavadni dogodki celotne dediščinske zgodbe zavzamejo svoj položaj v tej dediščini? Prelomni dogodki so reprezentirani prek različnih medijev in so kot taki pogosto osrednji simboli dediščinske zgodbe, toda njihovi avtentični kraji bi danes pri snovanju dediščine morali biti še posebej pomembni, ker vsaka sodobna dediščina v svoje okvire prej ali slej vključuje tudi možnosti turistične rabe. Sodobni kulturni turisti pa so vse bolj izobraženi in sofisticirani, iščejo »prave izkušnje «, ki jim bodo dale globlji pomen, medtem ko jih umetno ustvarjeni »produkti « in virtualni svetovi ne zadovoljijo več tako zlahka (Yeoman 2008: 166-67, 172).

Avtentičnost je pojem, ki že od MacCannellove (1973) vpeljave pomeni pomembno smer razmišljanja v turističnih raziskavah (Wang 1999: 349). Nikoli ni povsem jasna, polna je različnih omejitev in mnogokrat je izhodišče za številne zablode. Posebno ko govorimo o krajih, jim njihova » avtentičnost « pravzaprav odreja določen položaj $\mathrm{v}$ razmerju do vseh drugih položajev v določenem redu stvari (Babič 2009: 122-23). Tako tudi Ryan v uvodu v zbornik, ki govori o povezavi med turizmom in bojišči in kjer ga zanimajo predvsem ekonomija, 
kulturna politika ter interpretacija in upravljanje takih dediščinskih krajev, o konstituciji njihove avtentičnosti pravi:

\begin{abstract}
Že zdavnaj sem prišel do sklepa, da je to vprašanje napačno. Kar bi nas moralo bolj zanimati, je »avtorizacija « zgodb, ki so konstruirane o dogodkih, interpretaciji in kulturi. V smislu, kdo avtorizira avtentičnost? Kdo avtorizira pripovedovanje zgodb in s kakšnim namenom je ta avtorizacija podana? To vprašanje je pomembno, ker ta avtorizacija pomaga oblikovati izkušnjo kraja. (Ryan 2007: 2)
\end{abstract}

Čeprav se tesna povezava med krajem in prelomnim dogodkom pri dediščinski industriji danes zdi samoumevna, je tak kraj glede na gornjo poanto izbran med mnogimi drugimi možnimi kraji; avtoriziran je kot avtentičen in je potemtakem bolj ali manj popoln konstrukt. Avtentičnost takega kraja v nobenem primeru ni ontološka, čeprav se je dogodek morda zgodil prav tam, saj avtentičnosti nikoli ne kaže razumeti zunaj reda označevalcev. Prvič, kljub temu, da kraj sam na sebi na dogodek ne more imeti vpliva, je njegova avtentičnost močno orodje za ustvarjanje njegovih povezav z drugimi kraji. S svojim položajem lahko predrugači celotno strukturo dediščine, njeno naravo, njen empirični red stvari in njeno neposredno samorefleksijo. V tem smislu tak avtoriziran kraj postane osrednja lokacija, položaj, ki naslavlja vse druge položaje v kulturi (dediščine). In drugič, prelomni dogodek je navadno serija različnih dogodkov, ki so lahko medsebojno vzročno-posledično povezani, lahko pa tudi vzporedni in torej drug na drugega nimajo neposrednega vpliva. $V$ tem smislu mora biti dogodek izbran in potem po empirični logiki lociran, četudi svojega fizičnega kraja (še) nima.

Kaj to pomeni za soško fronto? Njen prelomni dogodek je zadnja, dvanajsta ofenziva, tako imenovana kobariška bitka oziroma preboj ali »čudež « pri Kobaridu. ${ }^{7}$ Ta dogodek je v ostrem nasprotju $s$ številnimi obrambnimi strukturami, jarki, kavernami in drugimi vojaškooperativnimi tehnologijami, ki skupaj s predstavo o sicer neohranjenih obsežnih zaledjih (skladišča, bolnišnice, pokopališča, delavnice, bordeli in druga vojaška oskrbovalna infrastruktura) tvorijo hrbtenico ohranjenih ostalin soške fronte.

Dvanajsta ofenziva se je začela 24. oktobra 1917 ter v štirih dneh pripeljala do množičnega umika italijanske vojske $s$ Posočja in s tem do konca 888 dni trajajočih statičnih frontnih linij med avstro-ogrsko in italijansko vojsko. To je bil edini napad avstro-ogrske vojske na soški fronti, na pomoč pa so ji prišle tudi nemške enote. Ta bitka, ki je terjala najmanj trinajst tisoč življenj italijanskih vojakov ter pet tisoč življenj na avstro-ogrski in nemški strani (STA 2017), je z različnimi intenzivnostmi potekala vzdolž celotne frontne črte. 
Kobariška bitka se v to fizično krajino ostalin soške fronte, njenih frontnih linij, vojaških poti in železnic, ki so fronto povezovale z zaledji, v Zgornje Posočje umešča drugače. To drug(ačn)o geografijo sestavljajo številni preddogodki, načrtovanje, premiki enot, koncentracije sil, vremenske razmere, omrežje položajev, odločitve poveljnikov, topovska obstreljevanja na daljavo in slednjič niz bolj ali manj usklajenih prodorov, lokalnih spopadov, umikanja italijanskih enot, zavzemanja novih položajev in tako dalje (glej Torkar in Kuhar 2018). To je za razliko od statične fronte geografija dogodkov, smeri, vektorjev in ne krajev, območij, točk.

Kje torej, oziroma natančneje, na katerem kraju se je zgodil ta pre$b o j$ ? Kam dediščinsko locirati zgodovinsko točko preloma, brez katere se preboj ne bi zgodil tako, kot se je? Vprašanje je glede na gornje izhodišče naivno, tudi banalno, vendar za dediščino soške fronte pomembno ravno zato, ker je takšen preboj v siceršnjih razmerah dolgotrajnega statičnega frontnega bojevanja sam po sebi heterotopičen dogodek. Zgodovinsko namreč pomeni odklon, ki je posledica drugačne koncepcije boja ter novega načela načrtovanja in poveljevanja. $S$ tem da tak dogodek najde svoj položaj v homogenem prostoru frontnih linij, reflektira njihovo nepopolnost ter predstavlja »vire možnega in novega « (Babič 2009: 130). Preboj je torej heterotopija, ki »ni materializirana v nekem drugem kraju « in »nastane, ko izrinjena heterogenost taktično ujame pravi trenutek in se postavi redu naproti« (Babič 2009: 134).

Do tu vse lepo in prav. Toda kaj se zgodi, ko se tak inherentno heterotopičen zgodovinski dogodek, tako rekoč udejanjenje Certeaujeve prostorske taktike nasproti vladajoči prostorski strategiji (Babič 2009: 131), podvrže procesom dediščinskega preoblikovanja? Heterogena praksa, taktika, alternativna raba prostora, nenavadna deviacija ... vse, kar ta prodor predstavlja nasproti pozicijski vojni, vsa dezorganizacija, ki jo povzroči v nasprotnem taboru, vsa lokalno koncentrirana in mobilna moč, ki jo uporabi za dosego položaja, je v svojem bistvu nelokalizirana, dinamična heterotopija ali »drugo prostora « (Babič 2009: 134). V procesu dediščinjenja pa to drugo prostora neizogibno postane osrednja heterotopija soške fronte, ki s svojim položajem reflektira relacije vseh drugih položajev dediščine ter s tem suspendira, nevtralizira in sprevrača njeno celoto. Izvorni, frontnim linijam in vojaškooperativnim strukturam heterogen dogodek se $\mathrm{v}$ sodobni prostor dediščine soške fronte vpiše kot $\gg$ drugi prostor «, ki akumulira tudi različne čase vojnega ter pred- in povojnega dogajanja: muzej s pripadajočo dokumentacijo, arhivom, knjižnico in podobnim (Foucault 1984: 7).

Snovalci Kobariškega muzeja prve svetovne vojne so tako imenovani »čudež« pri Kobaridu ali kobariško bitko v svojih prostorih 
postavili v izhodišče svoje pripovedi: obiskovalci muzeja si tako najprej ogledajo filmsko (dia)projekcijo poteka dvanajste ofenzive, dodatno pa je prikazana in razložena tudi na posebni maketi v muzejskih prostorih. ${ }^{\mathbf{8}}$ Šele po ogledu reprezentacije tega dogodka sledijo številni drugi vidiki soške fronte. Kobariško bitko je mogoče konzumirati tudi in situ prek specializiranih vodičev v organizaciji Fundacije. Ta razlaga premikov čet in prebojnih akcij navadno poteka v rekonstruiranih vojaških strukturah na Kolovratu, ki je edini resnični produkt Fundacije od šestih tovrstnih muzejev na prostem na Poti miru od Alp do Jadrana. ${ }^{9}$

Tam ima Fundacija tudi svojo informacijsko točko (Klavora 2016: 136), locirana pa je na razglednem grebenu, od koder je mogoče $\mathrm{v}$ lepem vremenu videti dolino Soče v smeri od Kobarida proti Tolminu in Krnsko pogorje, kjer so potekale številne drame soške fronte in kjer so predstavljene nekatere vojaške strukture in z njimi povezani vojaško-inženirski podvigi v visokogorju.

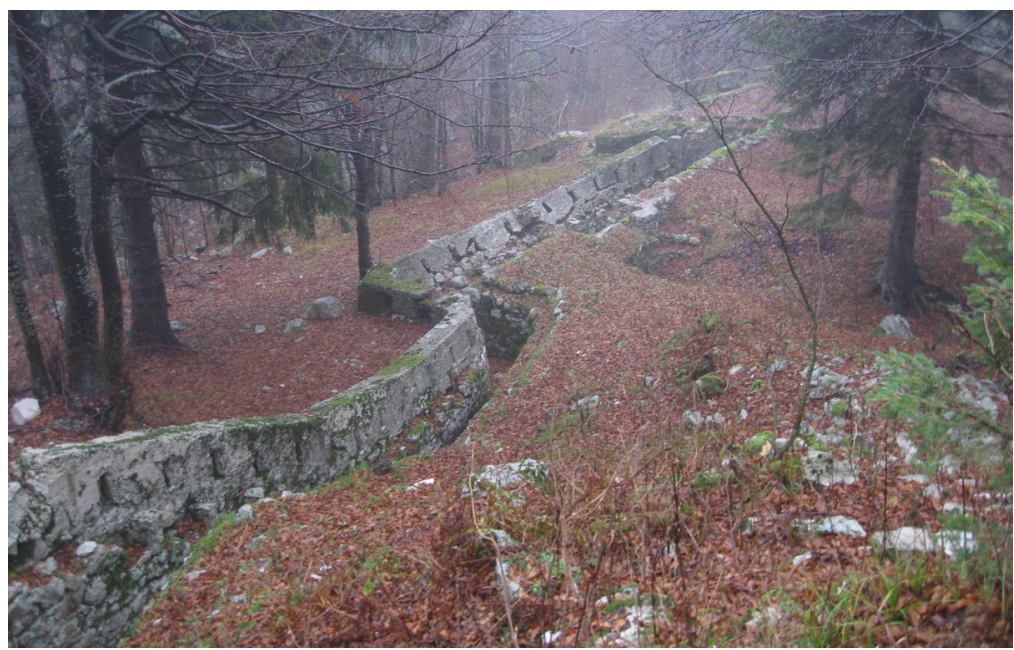

Slika 3: Nekoliko težje dostopen muzej na prostem Zaprikraj visoko v gorski dolini nad Drežniškimi Ravnami z odlično ohranjenimi originalnimi ostalinami soške fronte (foto: Boštjan Kravanja).

Zavedam se, da se temu kontekstu pri muzejski predstavitvi soške fronte ni mogoče izogniti. Kvaliteta Kobariškega muzeja je v tem, da temelji na zgodbi ljudi, udeleženih v vojni, in da v ospredje venomer postavlja gorje, ki ga vojna prinese v življenje vseh, ki se z njo srečajo. Toda inicialni poudarek na eni sami, četudi prelomni bitki tu predstavlja samostojen žanr dediščinske pripovedi.

9 Vsak muzej na prostem na Poti miru je unikaten. Nekatere odlikuje ohranjenost, druge funkcionalnost, dostopnost, urejenost in podobno. Upravljajo jih lokalna društva, ki so jih navadno tudi ustvarila ter jih vzdržujejo, dopolnjujejo, spreminjajo, promovirajo in uporabljajo po svoji presoji. Fundacija sicer bdi nad temi muzejsko preoblikovanimi kraji, nima pa neposrednega vpliva na njihovo upravljanje, niti si njeno osebje ob siceršnjih preštevilnih nalogah in dejavnostih v zvezi s Potjo miru in celotno dediščino soške fronte tega ne more privoščiti. 
Čudež pri Kobaridu torej niti nima realnega kraja, ker je potekal vzdolž celotne frontne črte, niti ni bil trenutek, ker je potekal več dni. Avtorja njegove pred kratkim izdane podrobne vojaške analize (Torkar in Kuhar 2018) sta v intervjuju ob izidu knjige Kobarid označila kot »etapni cilj [...] prvo večje mesto na italijanski strani, ki je padlo v roke napadalcev « (Dovjak 2018), in ne kot dejanski kraj prodora. Še več, v nemških in avstro-ogrskih vojaških dokumentih je govora o » preboju pri Tolminu in Bovcu «. Da je ta večlokalen dogodek danes lociran v Kobarid, je torej posledica njegovega dediščinjenja, ne nazadnje pa beseda Kobarid (Caporetto) Italijanom še danes pomeni »sinonim za presenečenje in kaos « (Dovjak 2018) oziroma katastrofalen poraz, debakel. V tem prvem smislu je bila dediščina soške fronte vzpostavljena kot klasična heterotopija, muzej, ki je spremenil tako identiteto Kobarida kot tudi identiteto soške fronte. $V$ tem drugem smislu pa je »čudež pri Kobaridu «, ki se je inicialno usidral kot eden od temeljnih pomenov soške fronte, izpostavil njene poražence.

Tako ni presenetljivo, da ob siceršnjih uspehih Kobariškega muzeja takoj po njegovi ustanovitvi ${ }^{\mathbf{1 0}}$ danes za enega od ključnih šteje dejstvo, da je postopno postal tudi izobraževalna destinacija italijanskih šol in fakultet, česar si še pred dvajsetimi leti ni bilo mogoče zamišljati. Prav v duhu preseganja te travme in povezovanja slovensko-italijanskega obmejnega prostora je leta 2000 nastal tudi Kobariškemu muzeju vzporedni projekt Fundacije in njene Poti miru, ki je v dediščinski prostor soške fronte vnesel naslednji niz heterotopij.

\section{STATIČNA FRONTNA LINIJA IN NJEN MIR}

Fundacija je bila leta 2000 ustanovljena zato, da bo znanstveno nadgradila dediščino soške fronte in uredila tematske poti in situ vzdolž frontnih linij (Kravanja 2014: 99; prim. Testen in Koren 2015: 189). Že Kobariški muzej je sredi 1990-ih let uredil Kobariško zgodovinsko pot, ki je poleg ostalin soške fronte vključevala še rimske in poznoantične arheološke ostaline ter nekaj najlepših naravnih znamenitosti v okolici Kobarida (Kravanja 2014: 98).11 Toda v Fundaciji so

11 Kobariški muzej je $\mathrm{v}$ prvih letih po ustanovitvi nasploh veliko vlagal $\mathrm{v}$ krajevne znamenitosti. Stanje urejenosti zgodovinsko pomembnih krajev je bilo namreč $v$ Kobaridu in okolici še v 1980-ih letih slabo. Kobariški muzej je prevzel nekaj od teh temeljnih funkcij, medtem ko so v okoliških vaseh pri urejanju dediščine, ki se 
se tovrstnih pešpoti lotili z izhodišča frontnih linij, čeprav so pri tem upoštevali tudi naravne ambiente, splošne kulturne znamenitosti območja in druge turistične vsebine ob teh poteh (Testen in Koren 2015: 191-92).

Kot sem na kratko navedel že v uvodu, je bilo do leta $2007 \mathrm{v}$ okviru Fundacije urejenih $100 \mathrm{~km} \gg$ Poti miru v Zgornjem Posočju « $s$ šestimi muzeji na prostem, leta 2015 pa so traso razširili na $300 \mathrm{~km}$ obsegajočo »Pot miru od Alp do Jadrana «, ki vključuje še dodatnih devet muzejev na prostem na obeh straneh slovensko-italijanske meje, tematski park v Tržiču (Monfalcone) ter celo vrsto drugih obeležij in objektov (Testen in Koren 2015: 193). Fundacija je skupaj z ureditvijo tega obsežnega tematsko-krajinskega parka prevzela še številne druge naloge. Tako je na primer Zdravko Likar, eden ključnih pobudnikov ustanovitve tako Kobariškega muzeja kot Fundacije, v našem intervjuju novembra 2018 izpostavil povezovanje s sosednjim italijanskim prostorom in pripadajočo čezmejno politiko. ${ }^{12}$

Fundacija je tako hitro postala samostojna, od Kobariškega muzeja ločena ustanova, ki koordinira delo številnih muzejskih in raziskovalnih institucij, ki se ukvarjajo z zgodovino soške fronte (glej Klavora 2016: 134), skrbi za tekoče razstave v svojih prostorih ter razvija izobraževalno funkcijo Poti miru in njeno zgodovinsko-turistično ponudbo, hkrati pa je to tudi nacionalni projekt. Formalno je namreč Fundacijo ustanovila Vlada Republike Slovenije (Testen in Koren 2015: 189), ki jo tudi redno financira, lastnik njene stavbe v Kobaridu je Ministrstvo za obrambo, vlada jo občasno uporablja za diplomatski protokol, s svojimi gosti pa jo obiskujejo tudi številni veleposlaniki tujih držav (Kravanja 2018b: 106).

Gledano skozi optiko naše heterotopološke analize je ta projekt s poudarkom na vrednoti miru v krajino Zgornjega Posočja vnesel novo dimenzijo, ki je več od organiziranega spominjanja na žrtve soške fronte (Seaton 2018). To je bilo namreč deloma izpostavljeno že od samega začetka snovanja te dediščinske zgodbe, kajti že ustanovitelji Kobariškega muzeja so njegov pomen utemeljevali s protivojnim, mirovnim sporočilom in prav zaradi tega prejeli najvišje evropsko priznanje (glej op. 10). Toda Fundacija je ta pomen dediščine soške fronte

je nanašala predvsem na preteklo kmečko življenje, pomagale nekatere sodelavke Goriškega in Tolminskega muzeja (na primer kustodinji Inga Miklavčič-Brezigar in Karla Kofol na Breginjskem).

12 Ob tem se moramo zavedati, da gre pri tovrstnih intervjujih s predstavniki institucij bolj za utečeno in velikokrat ponovljeno predstavitev, ki jo je mogoče najti tudi v številnih drugih besedilih (glej npr. podobno navedbo v Clarke, Cento Bull in Deganutti 2016: 666). 
neposredno izpostavila $\mathrm{v}$ imenu in logotipu, ${ }^{13}$ ustvarila njeno enotno podobo na terenu in tako zgradila potencialno prenosljivo dediščinsko blagovno znamko. Po zgledu spominskih območij v Dolomitih in Karnijskih Alpah je torej dediščino frontnih linij poimenovala Pot miru (Testen in Koren 2015: 185-86), v svojih predstavitvah te poti pa poskuša naracijo o vojaških operacijah in tehnologijah vojne podrediti temu krovnemu mirovnemu sporočilu. ${ }^{\mathbf{1 4}}$

$\mathrm{V}$ tem smislu pomeni Pot miru naslednji prevoj v procesu lokaliziranja (e)utopij, saj podobno kot prej obravnavana kobariška bitka »drugo prostora «(Babič 2009: 134) tokrat postane sam pojem miru, ki je z dejanskim zgodovinskim dogajanjem nekompatibilen oziroma celo v paradoksu. Pojem miru je sicer del širše uveljavljene navade spominjanja na žrtve različnih pobojev, vojn, grozodejstev in podobnega ter ima tudi konvencionalne načine uprostorjenja (glej Ziino 2012). To so spominski parki, poti, pokopališča in komemorativni dogodki oziroma romanja $\mathrm{k}$ tem specifičnim svetim krajem. Tako kot druge heterotopije tudi tovrstni kraji s svojim položajem reflektirajo relacije vseh drugih položajev prostora in $s$ tem nevtralizirajo, pa tudi pomensko sprevračajo njegovo celoto.

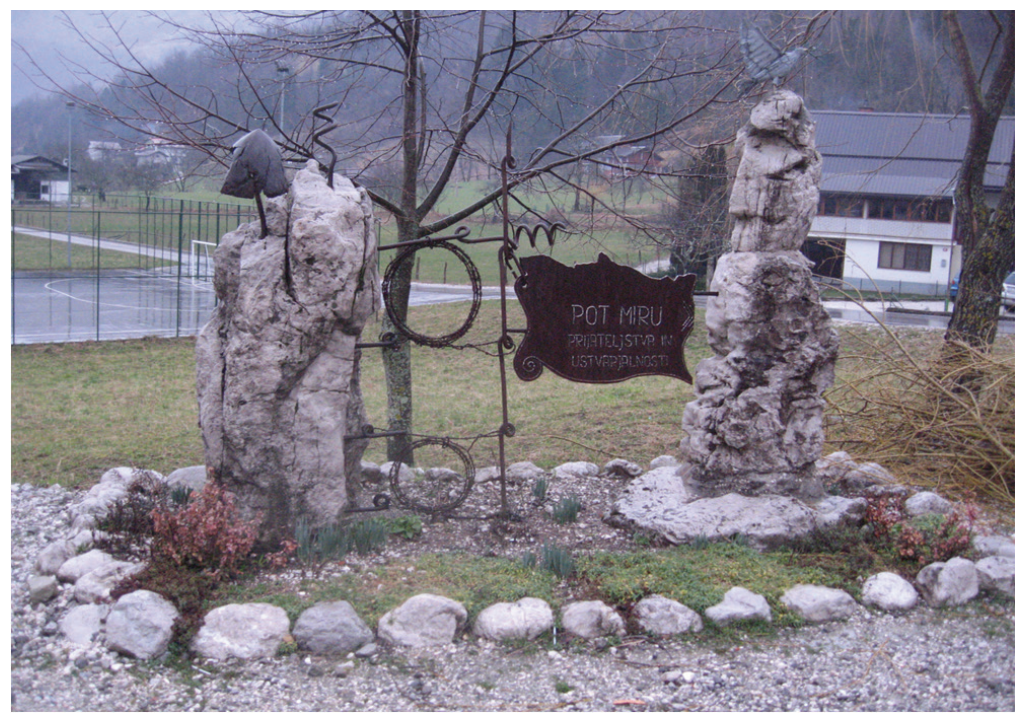

Slika 4: Obeležje Poti miru v vasi Drežnica nad Kobaridom (foto: Boštjan Kravanja). (glej Testen in Koren 2015: 191, op. 20).

$14 \mathrm{O}$ paradoksu med prezentacijo bojišč in spominskim poslanstvom te dediščine sem $\mathrm{z}$ različnimi poudarki že pisal (Kravanja 2018a: 93-7; 2018b: 111-13), a tu ne gre le za vprašanje sobivanja bojišč in pokopališč, ampak za še bolj temeljne kategorije miru in vojne. 
Toda v tem specifičnem primeru je prva heterotopična vrzel, na podlagi katere so nastale te, danes v okvir Poti miru vključene spominske strukture, vzniknila že v povojnem času fašizma, ko so italijanske oblasti posmrtne ostanke vojakov z vojaških grobišč na bojiščih in drugih pokopališč prestavile v kostnice (Kobarid, Redipuglia in Oslavia/ Oslavje) in na večja pokopališča, v krajino pa postavile številna spominska obeležja padlim, območje med vzpetinama San Michele in Sabotin pri Gorici razglasile za tako imenovani sveti prostor (Zona Sacra) in podobno (Saunders idr. 2013: 52).

$\mathrm{V}$ teh povojnih reorganizacijah pokopališke in spominske krajine lahko vidimo ustvarjanje heterotopičnih oziroma posredniških, vmesnih, drugih prostorov, ki so jih Italijani ustvarjali v procesu neposrednega vkomponiranja obstoječih krajev in njihovih položajev $\mathrm{v}$ povsem nov red in nove medsebojne relacije. ${ }^{\mathbf{1 5}}$ Razlika je v tem, da je bila (e)utopija fašistične Italije, ki je botrovala vzpostavitvi teh struktur, nacionalistična, a ta dobesedno dediščina Italijanov je danes na novo vzniknila iz druge heterotopične vrzeli, ki je hkrati antagonistična italijanskemu fašizmu, kozmopolitska v slavljenju evropskega miru in agonistična v odnosu do vseh, še posebno pa - če upoštevamo pomen Poti miru za preseganje obmejnosti tega prostora - Italijanov.

\section{VSEPRISOTNI NACIONALNI INTERESI}

Kraji pokolov, grozodejstev, bolečine, vojne in sramote so še posebno izpostavljeni mednarodnim neskladjem (disonancam), saj so pri njih navadno udeleženi tako zavojevalci kot tisti, ki to zavojevanje trpijo. Njihove percepcije se seveda radikalno razlikujejo. Politizacija kolektivnega spomina se tako na takih krajih dediščine pogosto odraža $v$ nacionalnih pretenzijah, ki prek vzvodov mednarodne, regionalne in lokalne politike uveljavljajo svoje parcialne interese. Logan in Reeves $\mathrm{v}$ uvodu $\mathrm{v}$ Kraje bolečine in sramote, kjer so zbrani primeri obravnave »težavne dediščine « $\mathrm{z}$ vsega sveta, ugotavljata:

$\mathrm{V}$ številnih primerih se državne oblasti s spreminjanjem zgodovine, izumljanjem tradicij in slavljenjem dediščine ukvarjajo tako, da

15 Pomembno je, da so italijanske oblasti v ta novi krajinski red vključile tudi žrtve na avstro-ogrski in nemški strani, ne le italijanskih posmrtnih ostankov, seveda pa je bilo postavljanje spomenikov in obeležij izraz politizacije vojne, saj je Italija iz Velike vojne vendarle izšla kot zmagovalka, kar je fašistična oblast izrabila za lastno glorifikacijo na ozemlju priključene Primorske (Saunders idr. 2013: 52). 
Gradnja nacionalne identitete je za doseganje politične in kulturne kohezije države pomembna. Pri tem je skrb za nacionalno dediščino primarni izkaz države tako $\mathrm{v}$ odnosu do državljanov kot do mednarodnopolitičnih struktur. V primeru Slovenije in njene (iz) rabe dedišcine prve svetovne vojne tako lahko govorimo o potencialu » mehke moči«, ki ga tovrstna »temačna « dediščina ponuja manjšim državam za uveljavljanje v mednarodni politiki Evropske unije in širše (Clarke, Cento Bull in Deganutti 2017).

Evropska unija je sicer edinstven mirovni projekt, ki pa je danes prepreden z notranjimi mednacionalnimi nasprotji. Današnji upravljavci Poti miru, torej zaposleni na Fundaciji, so v teh časih novega nacionalizma, pa tudi široke rabe informacijskih tehnologij in naraščajoče mobilnosti vseh vrst, tovrstnim silnicam izpostavljeni nekoliko drugače, kot so bili snovalci Kobariškega muzeja v 1990-ih letih. Na eni strani so mediatorji med zgoraj obravnavanima usmeritvama (re)prezentacij dediščine soške fronte, torej med lokalnozgodovinskimi vsebinami, ki dajejo prednost dolini Soče kot turistični destinaciji, in političnimi konteksti dediščinske zgodbe, kjer je pomembno ozaveščanje o tamkajšnjih dogodkih, »organizirano spominjanje « (Seaton 2018) na žrtve vojne, komunikacija vrednot miru, medsebojnega spoštovanja in podobno. $\mathrm{Na}$ drugi strani pa se morajo soočati tudi s številnimi pobudami v zvezi $s$ starimi ali tudi novimi nacionalnimi obeležji na Poti miru.

Nacionalni interesi posameznih držav, katerih vojaki so bili udeleženi na soški fronti, so se začeli odločneje kazati ob obeleževanju stoletnic prve svetovne vojne (2014-2018), čeprav so se tega latentnega problema zavedali že snovalci Kobariškega muzeja v 1990-ih letih. ${ }^{\mathbf{1 6}}$ Ob stoletnicah, ki so imele tudi pomemben vpliv na lokalno zavest o tej dediščini, so številne države, denimo Italija, Madžarska, Nemčija in Avstrija, pospešeno iskale možnosti za sodelovanje pri promociji te »nadnacionalne « oziroma skupne dediščine. Nekateri spominski kraji na Poti miru, denimo Ruska kapela, kapela na Javorci, Kobariški muzej in drugi, imajo pomembno vlogo v slovenskem zunanjepolitičnem diplomatskem protokolu (Kravanja 2018b: 106). svoje dokumentacije so $s$ tem kultivirali tudi nadnacionalno podobo soške fronte in tako posredno zamejevali njene morebitne nacionalno antagonistične reprezentacije. 
Vse to so sicer običajni postopki vzajemnega sodelovanja in izmenjav med državami, ko gre za večnacionalne dediščine. ${ }^{\mathbf{1 7}}$ Problem ozkih nacionalnih interesov pa je pri dediščini soške fronte vendarle vedno prisoten, najbolj prek komunikacije z različnimi obiskovalci, interesnimi združenji, mediji in podobnim. Kraji spopadov in vojn so pomemben simbol, katerega pomeni se lahko v času različnih kriz začnejo sprevračati tako $\mathrm{v}$ javnem diskurzu kot tudi in situ $\mathrm{z}$ različnimi posegi v njihovo ureditev. V skrajnih primerih lahko sprožijo velika mednacionalna trenja (glej Ziino 2012).

Tako so, denimo, nekatere madžarske nevladne organizacije financirale vključitev madžarščine na informacijske table na Poti miru (Milinković in Gerse 2018: 6). ${ }^{\mathbf{1 8}}$ Madžari so leta 2001 celo arheološko raziskovali bojišča soške fronte, ne da bi to prijavili lokalnim oblastem. Velike organizirane skupine madžarskih turističnih romarjev so v zadnjih letih postale dejstvo, ki ga dediščinske institucije v Posočju pozorno spremljajo. ${ }^{19} \mathrm{Ti}$ romarji organizirano čistijo »svoja « pokopališča (Milinković in Gerse 2018: 8) ter votivne trakove v barvah madžarske zastave pripenjajo tudi na nemadžarske grobove in osrednja svetišča pokopališč. Madžarsko veleposlaništvo je celo podalo pobudo za odkritje novega spomenika na območju Nove Gorice, ki bi bil posvečen padlim madžarskim vojakom (Milinković in Gerse 2018: 9), kar je v nasprotju s politiko Fundacije, ki na Poti miru obeležuje vse padle vojake ne glede na njihovo narodnost in pripadnost.

Madžarska je zgolj najnovejši primer tendenc po ustvarjanju tega, čemur lahko v odnosu do temeljnega sporočila Poti miru rečemo nacionalne heterotopije. Tako je svoj delež k temu prispevala tudi Slovenija, ki je nedaleč od bivše italijansko-slovenske meje na razglednem

17 Na primer upravljavca italijanske in nemške kostnice $\mathrm{v}$ Kobaridu in Tolminu sta italijansko oziroma nemško veleposlaništvo, cerkvica na Javorci je sicer pod upravo Zavoda za turizem in v lasti Občine Tolmin, toda njena funkcija v zaledju je bila že pred stotimi leti zavetišče vseh, ne glede na narod in celo ne glede na vero. Na vojaškem pokopališču v Logu pod Mangartom so pokopani avstro-ogrski vojaki vseh narodov, Ruska kapela je bila postavljena v spomin ruskim vojakom, ki jih je zasul plaz med gradnjo ceste čez Vršič, oltar v kaverni muzeja na prostem na Mrzlem vrhu so postavili madžarski vojaki itd.

18 Milinković in Gerse (2018) sta kot študentki našega meduniverzitetnega študijskega programa Creole pri vajah iz Antropologije prostora izvedli zelo kvalitetno raziskavo madžarske apropriacije prostorov soške fronte, kjer kot glavni diskurzivni formaciji Madžarov izpostavljata nacionalno herojstvo in suverenost kot nasprotje navidezno nevtralnemu okviru evropske složnosti, četudi slednja, kot pravita v sklepu, po podobnem načelu kot nacional(istič)ni diskurzi temelji na zamolčevanju lastne kolonialne zgodovine. Isonzó Expressz je madžarski zgodovinski vlak, ki v organizaciji turistične agencije MÁV Nosztalgia Ltd. iz Budimpešte $v$ dolino Soče za nekaj dni občasno pripelje tudi do petsto madžarskih turistov, ki organizirano obiščejo (predvsem »svoje «) točke na Poti miru (Milinkovič in Gerse 2018: 10). 


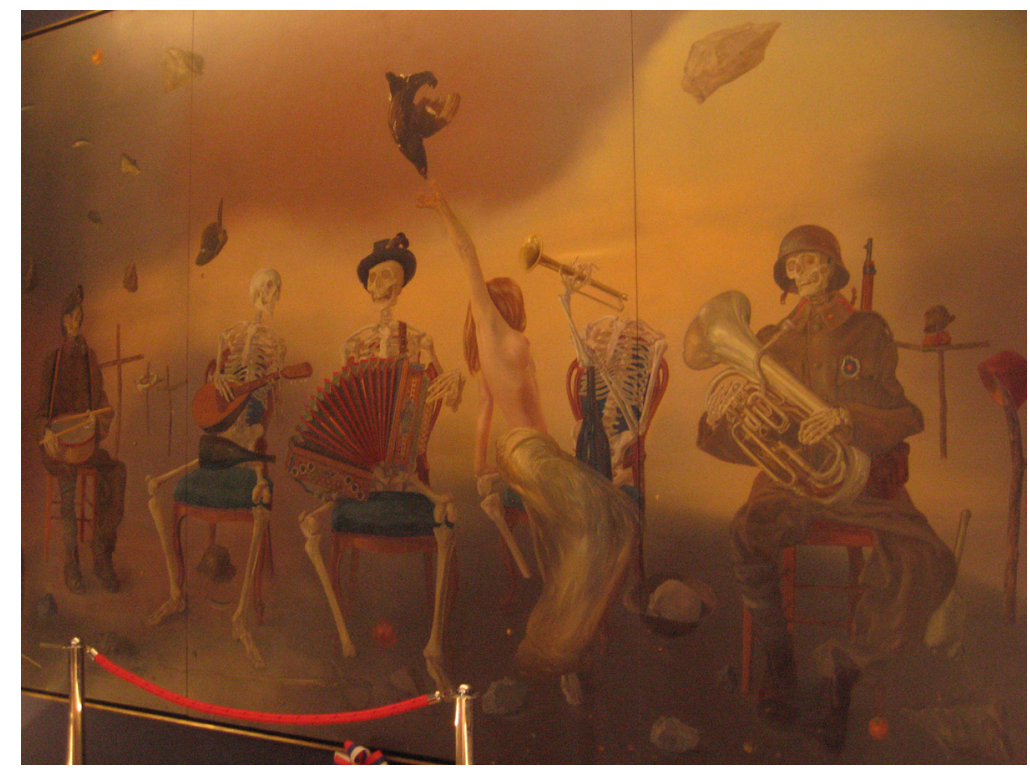

Slika 5: Segment slike Ples življenja in smrti Rudija Španzla na Cerju (foto: Boštjan Kravanja).

vrhu Cerje nad Mirnom leta 2011 za javnost odprla monumentalni Pomnik braniteljem slovenske zemlje. Spomenik je nastal na pobudo rodoljubnega Društva Tigr Primorske, katerega poslanstvo je predvsem osveščanje javnosti o vlogi antifašizma na Primorskem med obema vojnama. Spomenik stoji na Poti miru in od leta 2013 so njegove vsebine močno povezane $\mathrm{z}$ dediščino prve svetovne vojne. Vsebinsko so ga nadgradili s pomočjo čezmejnega sodelovanja med Slovenijo in Italijo, je priljubljena pohodniška točka in podobno. Toda poimenovanje in inicialni namen nekakšnega romarskega kraja slovenskega domoljubja $^{20}$ sta sprožila veliko negodovanja predvsem $\mathrm{z}$ italijanske strani, saj si je ta »pomnik «, skupaj z njegovo monumentalnostjo in lociranjem zgradbe na bivšo mejo, marsikdo po pravici tolmačil kot nacionalistični simbol, namenjen predvsem sosedom.

Pot miru in stoletnice vojne so izvorni pomen tega spomenika $\mathrm{v}$ veliki meri nevtralizirale, saj je Cerje danes pomembna informacijska in priljubljena razgledna točka, $v$ njegovih prostorih je postavljena stalna multimedijska razstava o prvi svetovni vojni, do konca leta 2019 pa gosti tudi nagrajeno razstavo kustosinje Tolminskega muzeja Karle Kofol Človek in vojna (Murkovo priznanje SED 2016). Zanimivo je, 
da na Cerju vsako leto septembra organizirajo prireditev ob mednarodnem dnevu miru, hkrati pa je bila 25. novembra 2017 na Cerju v prisotnosti državnih funkcionarjev slovesno odkrita slika Rudija Španzla Ples življenja in smrti, visoko simboličen spomenik padlim slovenskim vojakom v prvi svetovni vojni, ki se je je v medijih takoj prijela oznaka »slovenske Guernice «. Cerje je, skratka, z vsemi temi raznorodnimi vsebinami, simboličnimi poudarki ter konkretnimi navezavami vse bolj heterotopičen kraj, ki na enem mestu združuje vse smeri osmišljanja dediščine soške fronte, a v svojem bistvu ostaja slovensko nacional(istič)en » pomnik «.

\section{HETEROTOPIČNE VRZELI IN »DRUGO PROSTORA« V LOKALNOAMATERSKEM DEDIŠČINSKEM DELOVANJU}

Dediščino soške fronte $\mathrm{v}$ praksi sestavljajo tudi številne lokalne amaterske pobude, ki si sicer prizadevajo za njen nadaljnji razvoj, vendar tako, da poskušajo $\mathrm{v}$ celoten dediščinski paket vključevati nove vsebine, kraje in zgodbe, ki podobno kot zgoraj obravnavani primeri nacionalnih heterotopij poskušajo ustvarjati nove položaje in relacije med posameznimi kraji celotnega prostora dediščine (Babič 2009: 122-23). Kot smo videli v gornjih poglavjih, na tej dinamiki že od ustanovitve temeljita tudi osrednji instituciji dediščine soške fronte, Kobariški muzej in Fundacija. A ob trdnem okviru protivojnega in nadnacionalnega sporočila, ali prav zaradi njega, morata upravljati tudi z vse bolj številnimi drugimi pobudami znotraj celotnega dediščinskega prostora. Dober primer je sicer splošno vprašanje položaja amaterskih zbiralcev materialnih ostalin soške fronte (glej Kravanja 2018a), ${ }^{\mathbf{2 1}}$ toda parcialnih pobud in dejavnosti zbiralcev ali drugih navdušencev nad vojno in turizmom je še veliko več in vsaka si prizadeva uveljaviti svojo verzijo dediščinske naracije predvsem $\mathrm{v}$ fizičnem prostoru, manj pa $\mathrm{v}$ simbolnem smislu.

Ker gre v teh primerih večinoma za posameznike in društva, katerih moč je omejena, o pravih lokaliziranih iluzijah, utopijah,

21 Za okvir naše razprave o heterotopijah naj v zvezi z zbiralci zgolj poudarim, da obstoj številnih amaterskih zbirk še ne pomeni, da zbirke same na sebi že tvorijo heterotopijo. Njihov prostor se je namreč kot heterotopija oziroma heterotopična vrzel lokaliziral šele s tistimi zbiralci, ki so z ureditvijo popisa svojih artefaktov s pomočjo Tolminskega muzeja dobili možnost, da svoje zbirke odprejo za javnost in tako dobijo svoje mesto tudi v okvirih Fundacije, ki jih sicer na kratko, pa vendarle, predstavlja v svojih razstavnih prostorih. 
fantazijah in podobnem ne moremo govoriti. Domet njihovega vpliva na vse druge položaje $\mathrm{v}$ širšem dediščinskem prostoru je omejen, zato je mogoče v takšnih, od Poti miru neodvisnih pobudah bolj kot »prave « heterotopije videti heterotopične vrzeli (Meijer-van Mensch 2017: 25). Z vzpostavitvijo in lokalizacijo različnih novih vsebin namreč takšne pobude ne dosegajo tiste kulminacije prostora in časa, ki je značilna za »prave « heterotopije, čeprav morda imajo ta potencial v eventualno ugodnejših razmerah $\mathrm{v}$ prihodnosti.

Primer takšne heterotopične vrzeli je diskurzivni prostor, ki je vzniknil iz vprašanja, kako (in ali sploh) v Pot miru vključiti amatersko narejeno Rommlovo pot $\mathrm{v}$ vasi Jevšček nad Kobaridom. ${ }^{22}$ Vključitev lika Erwina Rommla v Pot miru bi bila korak nazaj k poudarjanju vojaških veščin, taktike nemških enot, ki so odločilno pomagale avstro-ogrski vojski v 12. ofenzivi. Rommlova osebnost je še bolj kot s prvo povezana z drugo svetovno vojno, ko je zaslovel kot »puščavska lisica « in bil predmet številnih zgodovinopisnih razprav (Torkar 2016). Rommlova pot je tako lahko specifična »kulturnoturistična « znamenitost, ki pa se kljub zgodovinski prisotnosti mladega Rommla, ki je 26. oktobra 1917 osvojil Matajur, ne sklada zlahka z idejo Poti miru. Poleg tega je bil Rommel le eden od nemških častnikov nižjega čina, ki so se izkazali v 12. ofenzivi soške fronte. Zakaj bi torej morala biti posebej obeležena prav njegova osebnost, če ne zaradi zvenečega imena, ki si ga je pridobil v drugi svetovni vojni?

Podobne heterotopične vrzeli, ki se razprejo ob vprašanjih kompatibilnosti novih elementov dediščine $\mathrm{z}$ obstoječim redom Poti miru, je mogoče najti še v številnih drugih primerih. Tako se je v zgodnjem obdobju vzpostavljanja te dediščine za njeno promocijo zdel primeren lik Ernesta Hemingwaya, ki je v romanu Zbogom, orožje soško fronto prikazal skozi oči italijanskega poročnika, nastanjenega $\mathrm{v}$ solkanskem zaledju. Hemingway v romanu poleg raznih peripetij in osrednje ljubezenske zgodbe glavnega protagonista opiše umik italijanske vojske po »preboju pri Kobaridu «. Zgodba je bila s svojim osrednjim protivojnim sporočilom usklajena $\mathrm{z}$ načinom prezentiranja soške fronte, posebno ker je bil Kobariški muzej primarno osredotočen na zgodbe. Kljub fikciji je to bila prvoosebna pripoved vojaka, ki jo je spisal svetovno znani književnik. Toda Hemingwayev lik je z vse bolj 


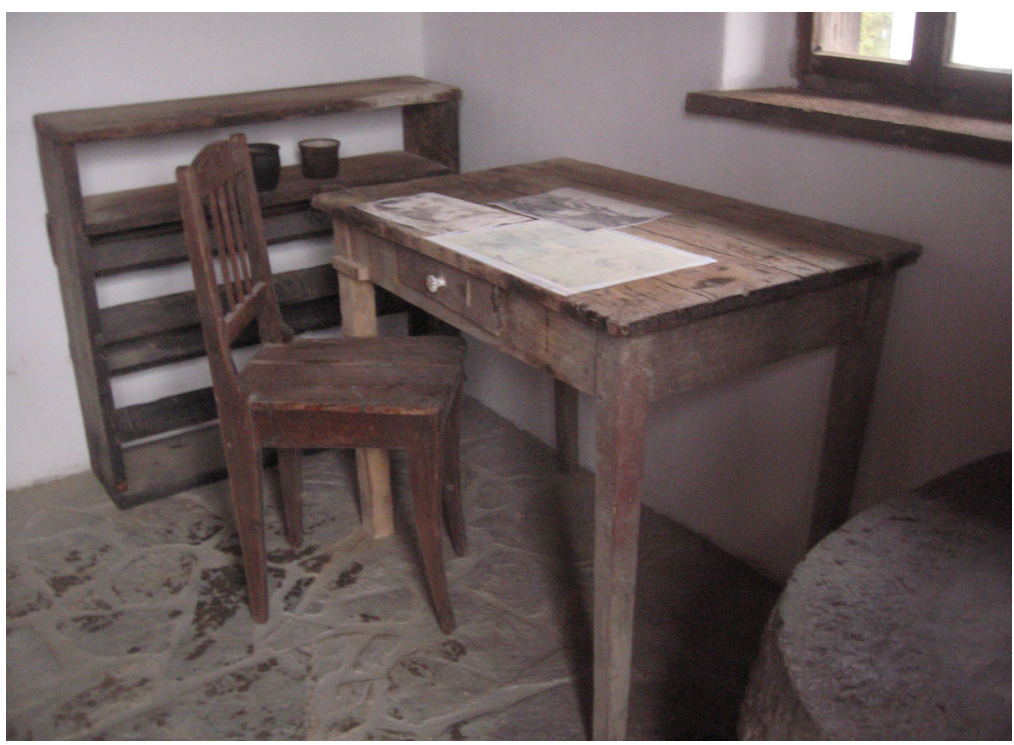

Slika 6: »Avtentična miza, za katero je Rommel načrtoval napad v noči pred osvojitvijo Matajurja v vasi Jevšček (Rommlova pot) (foto: Boštjan Kravanja).

izpopolnjenim znanjem o soški fronti izgubil svojo prepričljivost in se sicer v okvirih Kobariškega muzeja ohranil, a le kot obrobna vsebina, ki je bila prejkone privlačna predvsem za medije. ${ }^{23}$

Od novejših primerov takšnih ne povsem realiziranih heterotopij, ki pa vendarle niso zgolj »drugo prostora « v smislu latentnih taktik alternativne rabe prostora brez dejanske lokalizacije (Babič 2009), velja omeniti uprizoritev kobariške bitke na Kolovratu 17. septembra 2017 ob njeni stoletnici, ki jo je Kobariški muzej organiziral v sodelovanju s Fundacijo, Občino Tolmin, Kulturno-zgodovinskim društvom Triglav in številnimi drugimi klubi iz tujine, ki se ukvarjajo s tovrstnimi uprizoritvami. Resda na samem kraju uprizoritve danes ne stoji nikakršno obeležje, ki bi moralo biti nekako po sili vključeno v Pot miru. Tovrsten spektakel vojaške tehnologije in bojevanja se namreč z njo gotovo ne sklada najbolje. Dogodek pa je vendarle pustil sled v spletnem prostoru in predvsem kot potencialni precedens razprl heterotopično vrzel, ki sicer s svojim trenutnim položajem nima (še) moči

Glej na primer prispevek v Dnevniku 4. 7.2011 Hemingway ni nikoli prišel do Kobarida. Spletni vir: <https://www.dnevnik.si/1042456439>, 10. 5. 2019. Hemingwayev lik se je ohranil tudi $\mathrm{v}$ posameznih turističnih okvirih, tako je na primer nastanitvena kapaciteta nedaleč od Kobariškega muzeja, ki jo je kupil angleški podjetnik, poimenovana Hemingwayeva hiša. 
preurediti vseh drugih položajev v dediščini, je pa vendarle utrdila turistični diskurzivni prostor $\mathrm{v}$ dediščinskih okvirih, kar je ne nazadnje skupno vsem primerom heterotopičnih vrzeli v dediščini soške fronte.

Enega od morda najbolj heterotopičnih prostorov, ki v svojih samoniklih okvirih združuje tako dejanske heterotopije in heterotopične vrzeli kot tudi taktike alternativne rabe dediščinskega prostora soške fronte, tvori trinajst članov Društva 1313, ki so z ostalinami soške fronte povezane aktivnosti začeli kot zbiralci že v 1980-ih letih. Leta 2000 so uredili muzej na prostem na strateški avstro-ogrski točki Ravelnik pri Bovcu, ki je vključena v Pot miru in zaradi dostopnosti služi predvsem izobraževalnim in turističnim namenom.

Društvo 1313 pa ob sicer zelo razvejani paleti svojega delovanja (turistično in šolsko vodenje po Ravelniku, organizacija s soško fronto povezanih dogodkov, pohodov in komemoracij, sodelovanje v medijih, celo dokumentarnih filmih itn.) vendarle velja za nekoliko posebno. Temu gotovo botruje dejstvo, da v javnosti že od samih začetkov nastopa $\mathrm{v}$ različnih nacionalnih uniformah, ki so jih nosili vojaki na soški fronti, poleg tega pa je osnovalo tudi gledališko skupino, ki na humoren način v kratkih skečih z veliko mero improvizacije in domišljije prikazuje vsakdanje življenje vojakov na fronti. Skupino poleg rednega sezonskega programa v trdnjavi Kluže rade najemajo šole in različne skupine, priljubljena je pri medijih, pogosto pa se znajde tudi v vlogi fotomodela za turističnopromocijske brošure in filme turistične destinacije doline Soče.

Kot prodorni posamezniki v siceršnji dediščinski krajini soške fronte člani tega društva uveljavljajo specifično naracijo, ki pogosto trivializira »težavnost « te dediščine. Tudi Ravelnik je bolj kot konservatorsko dosleden muzej na prostem privlačen kraj, ki so mu dodane številne rekonstrukcije vojaških struktur. Tovrsten pristop sicer ni tuj tudi nekaterim drugim najdostopnejšim muzejem na prostem na Poti miru (na primer Kolovrat in Sabotin), toda Ravelnik morda vendarle nekoliko izstopa po raznih dodatkih.

Kot eno najstarejših dediščinskih društev, specializiranih za soško fronto, je 1313 za upravljavce Poti miru tako rekoč folklora te dediščine, kar bržkone pomeni, da ta dediščina brez Društva 1313 ne bi bila takšna, kot je. Člani društva se namreč dobro znajdejo v vlogi posebnežev in s svojo pojavnostjo pogosto začinijo prenekatero lokalno družabno dogajanje v Zgornjem Posočju, veliko pa tudi gostujejo doma in $\mathrm{v}$ tujini. Za protokolarne dogodke, mednarodne komemoracije in druge slovesnosti $z$ nekoliko večjo težo jih organizatorji (na primer Kobariški muzej, Fundacija, občine, Posoški razvojni center in tako naprej) vendarle neradi angažirajo, saj se s svojo »ljudskostjo « ne skladajo s tovrstnimi protokolarnimi redovi. 


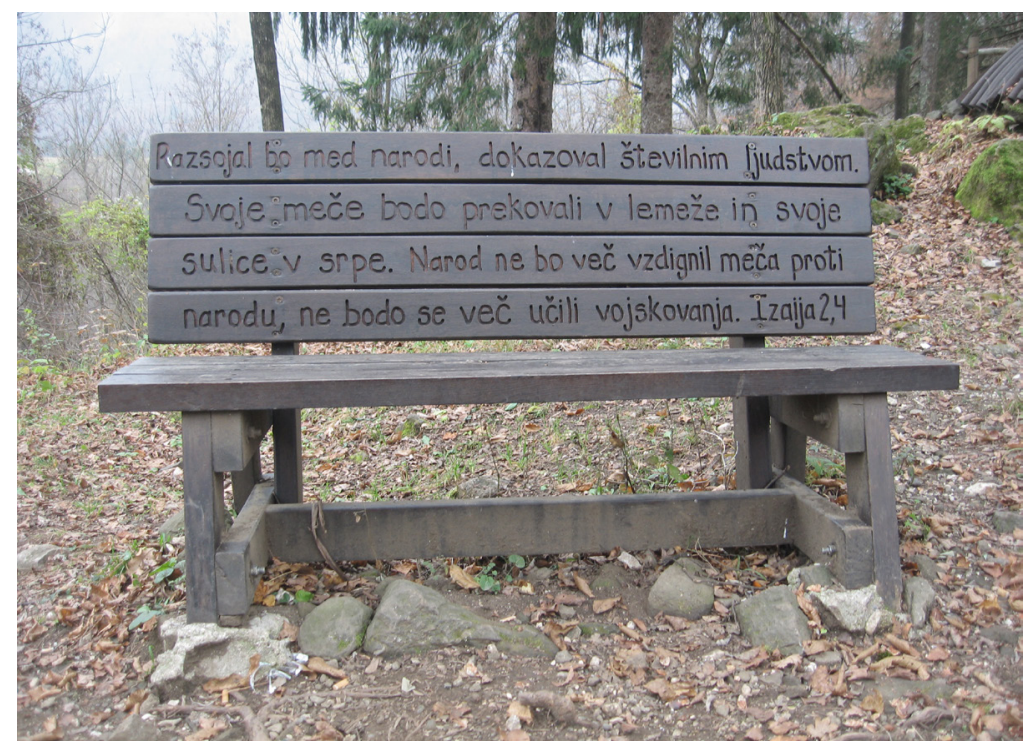

Slika 7: Klopi na Ravelniku z bibličnim citatom, ki so jih Društvu 1313 podarili pripadniki Jehovovih prič (foto: Boštjan Kravanja).

\section{SKLEP}

V pričujočem poglavju sem pokazal, kako si lahko pri razumevanju celotnega dediščinskega paketa soške fronte in procesov njegovega spreminjanja pomagamo s konceptom heterotopij, specifičnih drugih prostorov, ki iz nepovezanih, razpršenih in zgodovinsko preoblikovanih ostalin prve svetovne vojne v dolini Soče vedno znova ustvarjajo navidezno usklajen dediščinski red. Drugače kot v Saundersovi analizi krajinskega palimpsesta soške fronte, ki se je v dolino Soče nalagal celotno dvajseto stoletje (Saunders idr. 2013), so tu v ospredju heterotopije, ki kot lokalizirani drugi prostori služijo (pre)urejanju teh zgodovinskih vpisov v krajino.

$\mathrm{Z}$ njihovo pomočjo se je dediščina soške fronte uveljavljala na lokalnih, nacionalnih, čezmejnih in mednarodnih ravneh. Temeljni heterotopiji te dediščine, ki kot nekakšni dve strani istega kovanca ostajata stalnici njenega konceptualnega reda, sta se porajali iz odnosa med (turistično)razvojnimi in dediščinskimi diskurzi njenega osmišljanja. Prve predstavljajo sami začetki njenega ustvarjanja, ki izhajajo iz zbirateljske dejavnosti in so bili z ustanovitvijo Kobariškega muzeja prve svetovne vojne že demokratizirani, ne pa še demilitarizirani, drugi, torej strogo dediščinski diskurzi so utelešeni v Poti miru od Alp do Jadrana, ki s kombinacijo na eni strani pietetne in agonistične, na drugi 
pa zgodovinopisne in kozmopolitske drže poskušajo ustvariti celovito podobo pojma miru in situ.

Dediščino prve svetovne vojne so predvsem v času stoletnic med letoma 2014 in 2018 poskušali mobilizirati tudi kot povezovalni element skupne identitetne politike Evropske unije. Kar zadeva vlogo dediščine soške fronte v tem procesu, lahko povzamem poanto Clarka, Cento Bulla in Deganuttija (2017: 663), da so njeni upravljavci v večdesetletnem razvoju prešli skozi tri načine spominjanja tega zgodovinskega konflikta: antagonističnega, agonističnega in kozmopolitskega (glej op. 4). Ti načini so šli z roko v roki s prepoznavanjem potencialov dediščine prve svetovne vojne za udejstvovanje Republike Slovenije v evropski politiki, pri čemer se je kozmopolitska naracija zdela najprimernejša. $V$ pričujočem poglavju sem te različne vrste naracije uporabil kot izhodišče za identifikacijo temeljnih utopij, na osnovi katerih se je prezentacija dediščine soške fronte udejanjala v obliki heterotopij.

$\mathrm{Na}$ začetku je namreč dediščina soške fronte hote ali nehote $\mathrm{z}$ izpostavljanjem kobariške bitke in implicitno z njo povezanega poraza Italijanov ustvarjala antagonistične diskurze, ki sicer opredeljujejo táko dediščino, ki ostro razlikuje med prijatelji in sovražniki (Clarke, Cento Bull in Deganutti 2017: 663). V nadaljevanju se je osredinila na agonistično naracijo, ki odpira prostor vsem udeleženim v konfliktu ter rekontekstualizira žrtve in krivdo (prav tam), tu pa se je nanašala predvsem na travmatizirano italijansko stran, ki je pred dobrimi desetimi leti postopno začela sodelovati na spominskih dogodkih in obiskovati Kobariški muzej. Slednjič je, posebno izrazito v času obeleževanja stoletnic prve svetovne vojne, zavzela kozmopolitsko držo, ki se osredotoča na žrtve trpljenja, ki ga vojna prinaša vsem udeleženim ne glede na zmagovalce in poražence.

Čeprav te tri faze različnih diskurzivnih poudarkov niso potekale tako, da bi antagonistično nadomestila agonistična in slednjo kozmopolitska, ampak so prej potekale vzporedno, se medsebojno prekrivale in se na različnih ravneh artikulirale različno intenzivno, jih je bilo mogoče identificirati tudi v konkretni krajini. V pričujočem poglavju sem pokazal, kako je vsaka od teh naracij ustvarila svoje specifične heterotopije, druge prostore, ki so se $\mathrm{v}$ celoto dediščine vpisali kot atraktorji novega reda stvari, tako rekoč kot novi položaji ali situacije. Tem situacijam pa ves čas zelo pozorno sledijo upravljavci dediščine soške fronte, saj je od tega odvisno preživetje njihovih institucij (glej Kravanja 2018b).

Tako je začetna faza poudarjanja » kobariške bitke « ustvarila muzej, naslednja faza poudarjanja miru kot univerzalne vrednote je ustvarila konservacijo frontnih linij kot statično kuliso za pohodništvo, izobraževanje in »organizirano spominjanje« (Seaton 2018) na vojne žrtve, 
priprave na obeleževanje stoletnic pa so osmišljanje te dediščine še bolj usmerile v spominski vidik na žrtve in trpljenje vseh udeleženih v vojni. Temu ustrezno je nastal heterotopičen niz ali omrežje novih spominskih obeležij, številnih komemorativnih dogodkov, razstav, registra padlih in cele vrste medinstitucionalnih povezav. Intenzivnemu obdobju stoletnic sledijo nove, $s$ turističnorazvojnimi diskurzi povezane pobude, $\mathrm{v}$ okviru katerih je mogoče prepoznati dve smeri ustvarjanja heterotopij: prva poskuša uveljaviti lokalno vizijo soške fronte in $\mathrm{v}$ obstoječo infrastrukturo Poti miru vključiti nove »avtentične lokacije « vojaških operacij in dogodkov, druga pa se poskuša umeščati v različne dediščinske registre in se kot dediščinsko-blagovna znamka »Pot miru « uveljavljati na drugih podobnih destinacijah (na primer na solunski fronti).

Pri prvi varianti je bilo namesto »pravih « heterotopij mogoče identificirati heterotopične vrzeli, ki nastanejo kot posledica alternativnih prostorskih taktik in lokaliziranja utopij, ki z glavnino dediščine niso preveč kompatibilne, ne zberejo pa dovolj moči ali prepričljivosti, da bi s svojim položajem zares spremenile vse druge položaje v dediščinskem prostoru. V tem smislu ustvarjajo odmik, dvom, možnost drugega reda in ne pravih heterotopičnih prostorov. Druga varianta, torej ustvarjanje seznamov in umeščanje $\mathrm{v}$ nadnacionalne dediščinske registre, pa je stvar prihodnosti dediščine soške fronte, katere rezultati bodo gotovo nove heterotopije.

Morda bo to novo obdobje narekoval Unesco, ki se bo v kratkem moral pod številnimi pritiski tudi drugih modernih vojnih dediščin v svetu odločiti, pod kakšnimi pogoji jih bo vpisoval v svoj stalni seznam (Kravanja 2018b: 117-18). Na Fundaciji so se Unesca s prvim zbiranjem informacij od Italijanov, Belgijcev in Francozov lotili že leta 2014. S petnajstimi točkami na Poti miru so se leta 2016 vpisali na njegov poskusni seznam. Proces ustvarjanja dosjeja za vpis na stalni seznam dediščini soške fronte prinaša bolj celosten upravljavski načrt (izobraževalni programi, promocija, monitoring, razjasnjeno lastništvo, strokovne službe in tako naprej). ${ }^{\mathbf{2 4}} \mathrm{Ne}$ nazadnje so ena od pomembnih točk Unescovega dosjeja dejavniki vpliva na dediščino, med njimi pa je naveden tudi preveč množičen turistični obisk.

Zavedam se, da so tu predstavljeni rezultati pogosto $\mathrm{v}$ nasprotju z vsebinami, ki jih posredujejo upravljavci in različni zastopniki

24 Strokovna delovna skupina ta dosje pripravlja zgolj s šestimi najbolj primernimi in obvladljivimi točkami na Poti miru, saj ima stalni seznam precej strožje kriterije od poskusnega. Pot miru bo seveda kot celota ostala povezovalni element in bo ne glede na Unescove točke ohranjala temelje, na katerih je doslej gradila promocijo svoje dediščinsko-blagovne znamke. 
dediščine soške fronte $\mathrm{v}$ odnosih $\mathrm{z}$ javnostmi in $\mathrm{v}$ svojih formalnih dokumentih, kjer se ves čas poudarja izobraževalna, spominska, kontemplativna, svarilna, pa tudi ekonomsko-razvojna, trajnostna in še katera funkcija te dediščine. Semiologija prostora ima v tem smislu morda za današnji čas svoje omejitve, ki se kažejo predvsem v apolitičnosti njenih rezultatov, če ostajamo strogo v okvirih »dobesednega « branja znakov in relacij med njimi. »Branje znakov « je praviloma dokaj arbitrarno početje, kar se ne nazadnje ves čas kaže v nepredvidljivih interpretacijah, ki jih o dediščini soške fronte ustvarjajo njeni raznoliki obiskovalci in različne bolj ali manj kozmopolitske javnosti. Toda moč heterotopologije je ravno $\mathrm{v}$ tem, da ne reproducira trenutno uveljavljenih interpretacij dediščin, ampak poskuša s pomočjo diahrone perspektive identificirati tiste druge prostore in včasih nelokalizirano »drugo prostora « (Babič 2009), ki se v zloščene naracije o tej ali oni dediščini vrivajo ne glede na to, kako močno si jih njeni upravljavci in možganski trusti prizadevajo izključiti oziroma omejevati.

$\mathrm{V}$ tej dinamiki in kompleksnosti dediščine soške fronte se na trenutke zdi, da se pomen pojma heterotopije kot drugega prostora začne izgubljati v množici primerov. Zdi se, da lahko vsako novost, vsak diskurzivni premik, vsako novo idejo, ki najde položaj med že obstoječimi položaji v dediščinski krajini soške fronte, razumemo kot novo heterotopijo, heterotopično vrzel ali drugo prostora, ki zavzame specifično krajevno obliko in vpliva na celoto. Toda $\mathrm{v}$ heterotopijah lahko vidimo tudi permanenten proces, ki v obliki drugih, izključenih oblik prostora ves čas reorganizira tako obstoječi red kot prihajajoče ali pretekle nerede, podobno kot, denimo, hrup permanentno redefinira razmerje med glasbo in hrupom, ker (za)obsega vse možne zvočne krajine in je potemtakem inherenten del glasbe. $V$ izogib tej razvodenelosti pojma heterotopij naj torej sklenem, da sem z njegovim udejanjanjem $\mathrm{v}$ okvirih dediščine soške fronte v Zgornjem Posočju poskušal predvsem pokazati, kako lahko heterotopološka metoda služi za sistematizacijo pogleda na prostore sodobnih dediščin. Ob njihovih pogosto sugestivnih prostorskih ureditvah in praksah se namreč lahko vsakokrat vprašamo, kakšne utopije jim botrujejo.

\section{CITIRANE REFERENCE}

BABIČ, KAROLINA 2009 Heterotopije: drugi prostori ali drugo prostora?; Filozofski vestnik, št. 3, str. 121-136.

Cento Bull, Anna, in Hans Lauge Hansen 2016 On Agonistic Memory; Memory Studies, št. 4, str. 390-404. Spletni vir: https://purehost.bath.ac.uk/ws/ 
portalfiles/portal/116012882/On_Agonistic_memory_final_version_for_ Open_Access.pdf, 21.4. 2019.

Clarke, David, Anna Cento Bull in Marianna Deganutti 2017 Soft Power and Dark Heritage: Multiple Potentialities; International Journal of Cultural Policy, št. 6, str. 660-674.

DovJAK, RoK 2018 V 12. soški ofenzivi so se postavljali doktrinarni temelji sodobnega kopenskega vojskovanja; MMC RTV SLO, 27. oktobra 2018. Spletni vir: https://www.mohorjeva.com/images/buchdaten/Zadnja_bitka_-_Torkar_ MMC_RTV.pdf, 5.4.2019.

Foucault, Michel 1984 [1967] Of Other Spaces; Diacritics, št. 1, str. 22-27. Spletni vir: <http://web.mit.edu/allanmc/www/foucault1.pdf>, 9. 3. 2019.

1998 [1961] Zgodovina norosti v času klasicizma. Ljubljana: *cf.

2002 [1966] The Order of Things: An Archeology of Human Sciences. London: Routledge.

Gegner, MARTin, In BARt ZiIno 2012 Introduction: The Heritage of War: Agency, Contingency, Identity; Martin Gegner in Bart Ziino, ur. The Heritage of War, str. 1-15. Oxon in New York: Routledge

Johnson, Peter 2016. Brief History of the Concept of Heterotopia. Spletni vir: <http://www.heterotopiastudies.com/wp-content/uploads/2015/12/Brief-History-of-the-Concept-of-Heterotopia-word-dec-2016-pdf.pdf>, 9. 3. 2019.

2016b Interpretations of Heterotopia. Spletni vir: <http://www.heterotopiastudies.com/wp-content/uploads/2012/05/Interpretations-of-Heterotopia-pdf.pdf>, 9. 3. 2019.

KLAVora, MAšA 2016 Pot miru od Alp do Jadrana in dediščina soške fronte; Glasnik SED, št. 3-4, str. 134-136.

Kofol, KARLA 2015 »Privatne zbirke Gornjega Posočja ter njihovo sodelovanje s pooblaščenimi muzeji in pristojnimi institucijami; Roberto Dapit, Barbara Ivančič Kutin in Špela Ledinek Lozej, ur. Le collezioni uniscono: Collezioni ethnologiche, tradizione orale e turizmo cultural fra le Alpi e il Carso = Zbirke povezujejo: Etnološke zbirke, ustno izročilo in kulturni turizem med Alpami in Krasom, str. 271-281. Udine: Universita degli Studi di Udine, Dipartimento di Lingue e Letterature Straniere.

Kravanja, Boštjan 2014 Selling and Sharing Culture: On Relations between Cultural Heritage, Nature Conservation and Tourism Development Institutions in the Upper Soča Valley, Slovenia; Narodna umjetnost, št. 1, str. 89-112.

2018a Learning by Collecting: Amateur Collectors and their Shifting Positions in the Isonzo Front Heritagization and Tourism Adaptation; Folklore, št. 37 , str. 95-116.

2018 b Dediščina soške fronte kot izhodišče za razmislek o sodobnih pristopih k dediščinski politiki; Etnolog, št. 28, str. 105-122.

Logan, William, in Keir Reeves 2009 Introduction: Remembering Places of Pain and Shame; William Logan in Keir Reeves, ur. Places of Pain and Shame: Dealing with »Difficult Heritage «, str. 1-14. London: Routledge.

MacCannell, Dean 1973 Staged Authenticity: Arrangements of Social Space in Tourist Settings; American Journal of Sociology, št. 79, str. 589-603. 
Meijer-van Mensch, LĖontine 2017 Profiling and Reflecting on Collections and Collecting; Jože Hudales in Tanja Roženbergar, ur. Collecting and Collections in Times of War or Political and Social Change: COMCOL Annual Conference, Celje 2014, str. 19-27. Ljubljana: Znanstvena založba Filozofske fakultete.

Milinković, IVANA, In JUdit Gerse 2018 Hungarian Historical Narratives Related to the First World War in the Soća Valley. Ljubljana: Dokumentacija Oddelka za etnologijo in kulturno antropologijo Filozofske fakultete Univerze v Ljubljani, fond Krajine prve svetovne vojne v Dolini Soče 2018.

NACionalni OdBoR 2012 Nacionalni odbor za obeležitev 100-letnic 1. svetovne vojne (2014-2018). Spletni vir: <www.100letprve.si>, 3. 4. 2019.

Rodman, Margaret C. 2003 Empowering Place: Multilocality and Multivocality; Setha M. Low in Denise Lawrence Zuñiga, ur. The Anthropology of Space and Place: Locating Culture, str. 204-223. Malden: Blackwell Publishing.

RYAN, Chris 2007 Introduction; Ryan Chris, ur. Battlefield Tourism: History, Place and Interpretation, str. 1-10. Amsterdam: Elsevier.

Saunders, Nicholas, Neil Faulkner, Uroš Košir, Matija Črešnar in Sian Thomas 2013 Conflict Landscapes of the Soča/Isonzo Front, 1915-2013: Archaeological-Anthropological Evaluation of the Soča Valley, Slovenia; Arheo, št. 30, str. 47-66.

SeAton, Tony 2018 Encountering Engineered and Orchestrated Remembrance: A Situational Model of Dark Tourism and its History; Philip R. Stone idr., ur. The Palgrave Handbook of Dark Tourism Studies, str. 9-31. London: Palgrave Macmillan.

Sutton, Robert K. 2012 Commemorating the American Civil War in National Park Service Battlefields; Martin Gegner in Bart Ziino, ur. The Heritage of War, str. 108-124. Oxon in New York: Routledge.

STA 2017. Soška fronta v številkah. Slovenska tiskovna agencija. Spletni vir: https:// www.sta.si/soska-fronta/v-stevilkah, 12.3. 2019.

Testen, Petra, in Tadej Koren 2015 Učilnica na prostem - Primer Poti miru; Prispevki za novejšo zgodovino, št. 2, str. 183-198.

ToRkAR, BLAž 2016 Puščavska lisica ob soški postrvi: Delovanje Erwina Rommla v prvi svetovni vojni je tesno povezano s slovenskim prostorom in soško fronto; Delo, 3. junija. Spletni vir: <https://www.delo.si/sobotna/puscavska-lisica-ob-soski-postrvi.html>, 10.5. 2019.

Torkar, Blaž, In Miha Kuhar 2018 Zadnja bitka na Soči 1917. Celovec: Mohorjeva družba.

YeOman, IAN 2008 Tomorrow's Tourist: Scenarios \& Trends. Amsterdam: Elsevier.

WANG, NING 1999 Rethinking Authenticity in Tourism Experience; Annals of Tourism Research, št. 2, str. 349-370.

ZIINO, BART 2012 »We are Talking about Gallipoli After all «: Contested Narratives, Contested Ownership and the Gallipoli Peninsula; Martin Gegner in Bart Ziino, ur. The Heritage of War, str. 142-159. Oxon in New York: Routledge. 